University of Nebraska - Lincoln

DigitalCommons@University of Nebraska - Lincoln

1982

\title{
In Situ Study of the Physical Mechanisms Controlling Induced Seismicity at Monticello Reservoir, South Carolina
}

Mark D. Zoback

U.S. Geological Survey, zoback@stanford.edu

Stephen Hickman

U.S. Geological Survey

Follow this and additional works at: https://digitalcommons.unl.edu/usgsstaffpub

Part of the Earth Sciences Commons

Zoback, Mark D. and Hickman, Stephen, "In Situ Study of the Physical Mechanisms Controlling Induced Seismicity at Monticello Reservoir, South Carolina" (1982). USGS Staff -- Published Research. 403. https://digitalcommons.unl.edu/usgsstaffpub/403

This Article is brought to you for free and open access by the US Geological Survey at DigitalCommons@University of Nebraska - Lincoln. It has been accepted for inclusion in USGS Staff -- Published Research by an authorized administrator of DigitalCommons@University of Nebraska - Lincoln. 


\title{
In Situ Study of the Physical Mechanisms Controlling Induced Seismicity at Monticello Reservoir, South Carolina
}

\author{
Mark D. Zoback and Stephen Hickman \\ U.S. Geological Survey, Menlo Park, California 94025
}

\begin{abstract}
In two $\sim 1.1-\mathrm{km}$-deep wells, the magnitudes of the principal in situ stresses, pore pressure, permeability, and the distribution of faults, fractures, and joints were measured directly in the hypocentral zones of earthquakes induced by impoundment of Monticello Reservoir, South Carolina. Analysis of these data suggests that the earthquakes were caused by an increase in subsurface pore pressure sufficiently large to trigger reverse-type fault motion on preexisting fault planes in a zone of relatively large shear stresses near the surface. The measurements indicated (1) near-critical stress differences for reverse-type fault motion at depths less than $200-300 \mathrm{~m}$, (2) possibly increased pore pressure at depth relative to preimpoundment conditions, (3) the existence of fault planes in situ with orientations similar to those determined from composite focal plane mechanisms, and (4) in situ hydraulic diffusivities that agree well with the size of the seismically active area and time over which fluid flow would be expected to migrate into the zone of seismicity. Our physical model of the seismicity suggests that infrequent future earthquakes will occur at Monticello Reservoir as a result of eventual pore fluid diffusion into isolated zones of low permeability. Future seismic activity at Monticello Reservoir is expected to be limited in magnitude by the small dimensions of the seismogenic zones.
\end{abstract}

\section{INTRODUCTION}

In cases of induced earthquakes it is necessary to understand the responsible physical mechanisms in order to predict the likelihood and severity of future earthquakes and to define steps for hazard mitigation. In this paper, we describe an integrated set of in situ investigations designed to gain a physical understanding of the cause of earthquakes near Monticello, South Carolina, that began after impoundment of a 52-m-deep reservoir in December 1977.

Since Carder [1945] first showed a relationship between the impoundment of Lake Mead and subsequently occurring earthquakes, 63 other cases of reservoir-induced seismicity had been identified as of 1978 [Woodward-Clyde Consultants, 1979]. Two physical mechanisms by which reservoirs might induce earthquakes are commonly cited that were reviewed by Simpson [1976]: the load effect, in which the weight of impounded water adds to ambient stresses and thereby induces the earthquakes (see Gough and Gough [1976] on the 1963 Kariba earthquakes) and the pore pressure effect, in which increased subsurface pore pressure triggers earthquakes by reducing the effective normal stress on fault planes [Hubbert and Rubey, 1959]. Increased pore pressure at depth can result from the load of the reservoir as the rock is a compressible porous medium [Biot, 1941] and from the diffusion of fluid from the reservoir. For reasons which will be discussed later, we believe that fluid diffusion is the mechanism responsible for the induced earthquakes at the Monticello Reservoir. This mechanism has been shown to be important in cases of earthquakes induced by fluid injection [see Healy et al., 1968; Raleigh et al., 1972]. Simpson [1976], Bell and Nur [1978], Talwani and Rastogi [1979], and others have discussed the possible importance of fluid diffusion in cases where earthquakes are apparently induced by a relatively small subsurface pore pressure change associated with reservoir impoundment, but there

This paper is not subject to U.S. copyright. Published in 1982 by the American Geophysical Union.

Paper number 2B0647. has never been a test of this hypothesis. In the study described here we have attempted to test the fluid diffusion hypothesis through direct experimentation and to assess its implications with respect to the occurrence of future earthquake activity at Monticello Reservoir.

\section{Monticello Seismicity}

Monticello Reservoir is located in the Charlotte Belt of the Piedmont province in South Carolina (Figure 1a). The reservoir was impounded to serve a dual purpose: it provides cooling water for the Virgil C. Summer Nuclear Power Station and it serves as the upper reservoir in a hydroelectric pump storage facility (Figure $1 b$ ). Metamorphic rocks in the area (interlayered and folded gneiss, amphibolite, and schist) have been intruded by plutons of granite to granodiorite composition [Overstreet and Bell, 1965], which are quite common in the vicinity of the reservoir [Dames and Moore, 1974]. Secor et al. [this issue] describe the geology in the vicinity of Monticello reservoir in detail and discuss geologic constraints on the origin and potential hazard of the induced seismicity.

Figure 2 (modified after Talwani [1979]) shows the clear association between reservoir impoundment and subsequent earthquake activity. P. D. Talwani et al. (manuscript in preparation, 1982) discuss Monticello seismicity at great length, and we will only briefly summarize some of their observations throughout this paper. Beginning about 3 weeks after the start of pumping and impoundment, earthquake activity began to occur significantly above the background level. Maximum activity occurred in a pronounced swarm accompanying full impoundment in January and February 1978; it persisted for about 2 months and then rapidly subsided to a level of activity well above the background level.

Figure 3 [after Talwani et al., 1980] shows the distribution of seismicity around Monticello Reservoir for the period of December 1977 to September 1979 as determined with the seismic network shown in Figure $1 b$. The events seem to occur basically in three clusters; most events occur beneath 6959 


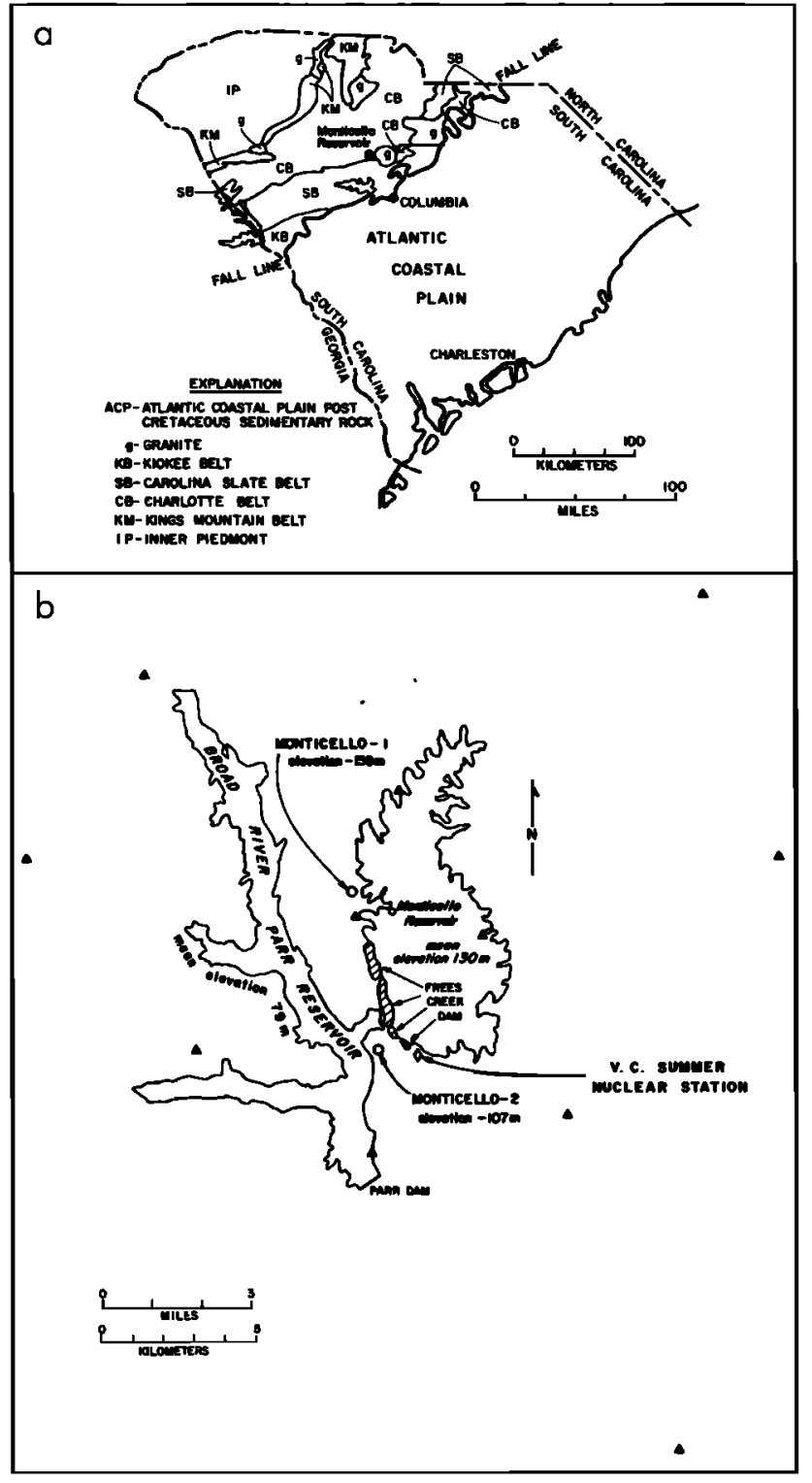

Fig. 1. (a) Map showing the location of Monticello Reservoir in the Charlotte Belt of South Carolina. (b) Location of seismograph stations (triangles) and two $\sim 1.1-\mathrm{km}$-deep wells that were drilled into the hypocentral zone of earthquakes occurring there (see Figure 3).

the center and near the west edge of the reservoir; there is a cluster of events near the south (primarily southwest) edge of the reservoir; and a third cluster, with many fewer events, occurs at the very northern end of the reservoir. The largest earthquake, magnitude 2.8, happened in October 1979, and although over 3000 microearthquakes have occurred since impoundment, fewer than 30 have exceeded $M=2.0$. The events are quite shallow, most occurring within $1.5 \mathrm{~km}$ of the surface [Talwani et al., 1980; Fletcher, this issue]. The issue of the focal depths of the earthquakes is discussed at greater length below.

Talwani et al. [1980] have computed composite focal plane mechanisms for events occurring in different areas around the reservoir. In all cases, the composite focal plane mechanisms indicate reverse faulting with relatively little oblique slip. Although a variation in nodal plane orientation is seen in different areas around the reservoir, on the average, nodal planes strike N-S to NW-SE, and the average direction of maximum horizontal compression is approximately ENEWSW.

Of the mechanisms mentioned previously, increased subsurface pore pressure is the suspected triggering mechanism in cases of reservoir-induced seismicity in reverse faulting environments because the effect of the weight of the water is primarily to increase the normal stress on fault planes and hence inhibit fault motion [see Snow, 1972]. As the reservoir-induced earthquakes at Monticello are caused by reverse faulting, our attention is focused on increased pore pressure at depth as the probable causative mechanism. Moreover, changes in pore pressure through fluid diffusion rather than load-induced pore pressure changes are suggested by the manner in which the zones of seismicity grew with time and the apparent time lag between fluctuations in reservoir level and seismic energy release [Talwani et al., 1980].

Bell and Nur [1978] showed that when a reservoir load is concentrated on the footwall side of a reverse fault there is a slight increase in the ratio of shear to normal stress. However, this effect does not seem to be applicable to the Monticello seismicity because many of the earthquakes occur directly beneath the reservoir where the load is uniformly distributed on both the footwall and hanging wall sides of the fault planes.

\section{Experimental Program}

In our approach to this problem, we have adopted as a working hypothesis the concept that the earthquakes are being induced by increased pore pressure at depth. Making the common assumption that the earthquakes result from slip on preexisting fault planes, we must know the orientation and magnitude of the principal stresses, the magnitude of pore pressure at depth, the frictional strength of the faults, and the orientation of potential fault planes in order to know if frictional sliding is likely to occur. As substantial information is available on the frictional strength of rock from both laboratory [see Byerlee, 1978] and field [see Raleigh et al., 1977] studies, in situ measurements of the stress field, pore pressure, and orientation of fractures and faults can be assessed in terms of the potential for failure to occur upon changes of any of these parameters. To examine directly the state of stress, pore pressure and permeability, and the nature of subsurface fault zones in the hypocentral zone of the earthquakes, two wells (designated Mont 1 and Mont 2) were drilled to depths of about $1.1 \mathrm{~km}$ directly into dense clusters of seismic activity (Figure 3) (see also Fletcher, this issue, Figures 2-4]. Both wells were drilled into granitic plutons intruding the surrounding metamorphic rocks. Except for zones of alteration around fracture zones in the wells, samples from the wells indicated the rock to be of granite to granodiorite composition. Following drilling, a series of measurements were conducted in each well. The measurements in well Mont 1 were conducted in July 1978, and those in Mont 2 were conducted in January 1979 and August 1980.

\section{Stress Measurements}

If the earthquakes at Monticello Reservoir are occurring in response to increased subsurface pore pressure (or surface load) resulting from impoundment of such a small reservoir (maximum depth $52 \mathrm{~m}$ ), the ambient state of stress must be 


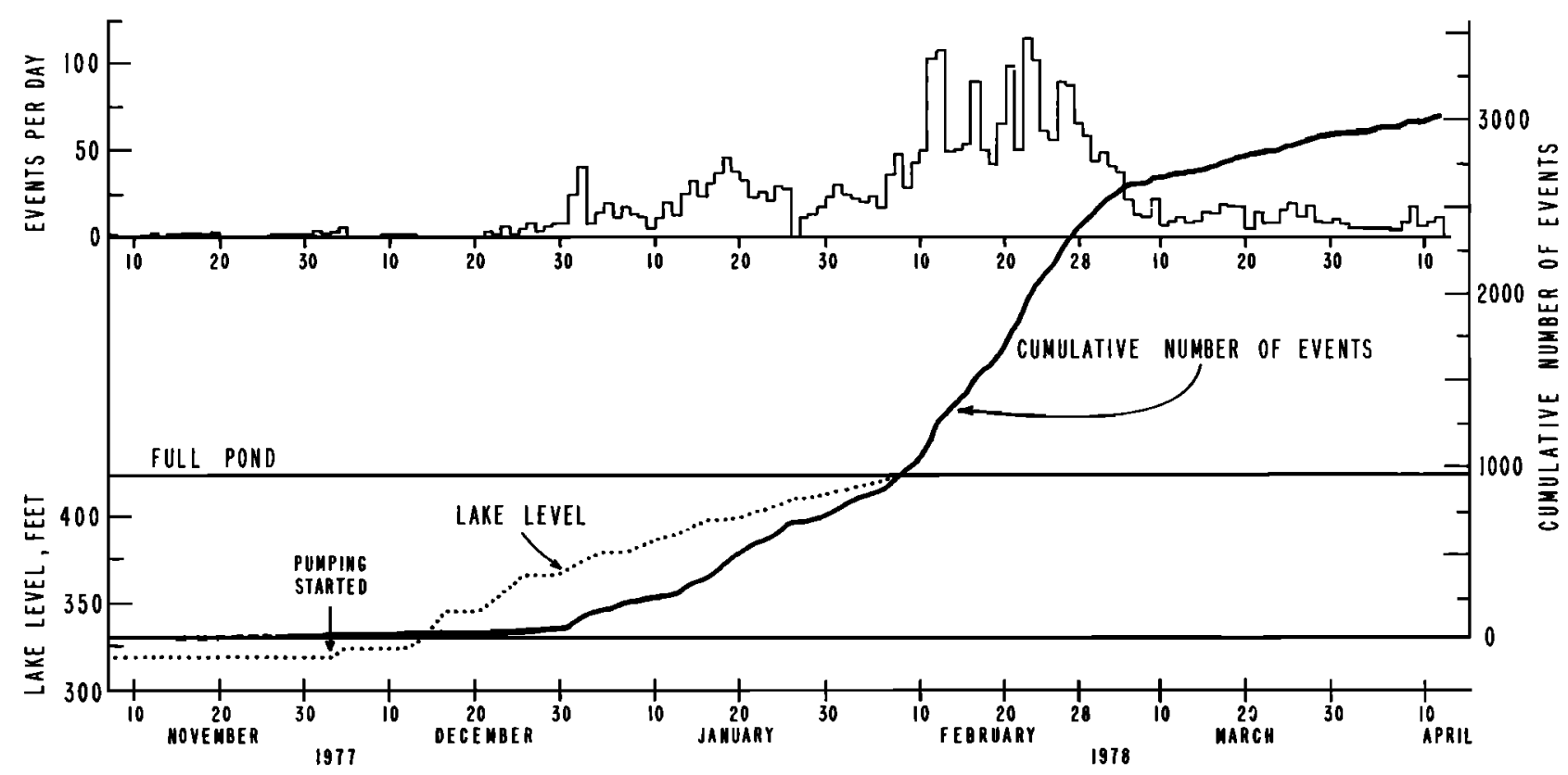

Fig. 2. Correlation between seismicity and lake level at Monticello Reservoir (modified after Talwani [1979]).

close to failure. To examine the state of stress at depth, hydraulic fracturing stress measurements were made at various depths in each well. The techniques used in the tests as well as the interpretative methods used are similar to those previously described by Zoback et al. [1977, 1980] and are only outlined below.

\section{Method}

In a vertical well the hydraulic fracturing technique basically assumes that one principal stress results from the overburden and is oriented parallel to the borehole. The initial propagation of the hydraulic fractures will be in a vertical plane oriented perpendicular to $S_{h}$, the least horizontal principal stress [Hubbert and Willis, 1957]. The assumption that the fracture propagates perpendicular to the least principal stress is well supported by the excellent agreement between hydrofrac, geologic, and seismologically determined stress field indicators [see Zoback and Zoback, 1980]. McGarr and Gay [1978] and others have presented data supporting the validity of the assumption of an approximately vertical principal stress direction that results from the lithostatic load.

The horizontal principal stresses are determinable from the pressure necessary to induce (or open) a vertical hydraulic fracture at the borehole, and the pressure at which the hydraulically isolated (shut-in) fracture comes to equilibrium. Determination of $S_{H}$, the maximum horizontal principal stress, requires the assumption of elastic behavior in the region surrounding the borehole. Although in many cases this assumption is clearly not valid and $S_{H}$ cannot be determined [cf. Zoback et al., 1977], this is not considered to be a problem in this study because the measurements were made in crystalline rock and in sections of the boreholes without detectable preexisting fractures and joints.

Hubbert and Willis [1957] derived the formula

$$
P_{b}=3 S_{h}-S_{H}-P_{p}+T
$$

relating the breakdown or fracture formation pressure $\boldsymbol{P}_{b}$ to the horizontal principal stresses $S_{h}$ and $S_{H}$, the pore pressure
$\boldsymbol{P}_{p}$, and the tensile strength $\boldsymbol{T}$ of the formation. When core is available for determination of $T$, an estimate of $S_{H}$ can be made using (1). In this study we use the following techniques for determination of $S_{h}$ and $S_{H}$. First, we use the stable instantaneous shut-in pressures attained in later pressurization cycles for determination of $S_{h}$ as well as the low flow rate pumping pressure measured downhole on those cycles. Second, in the manner of Bredehoeft et al. [1976], we used

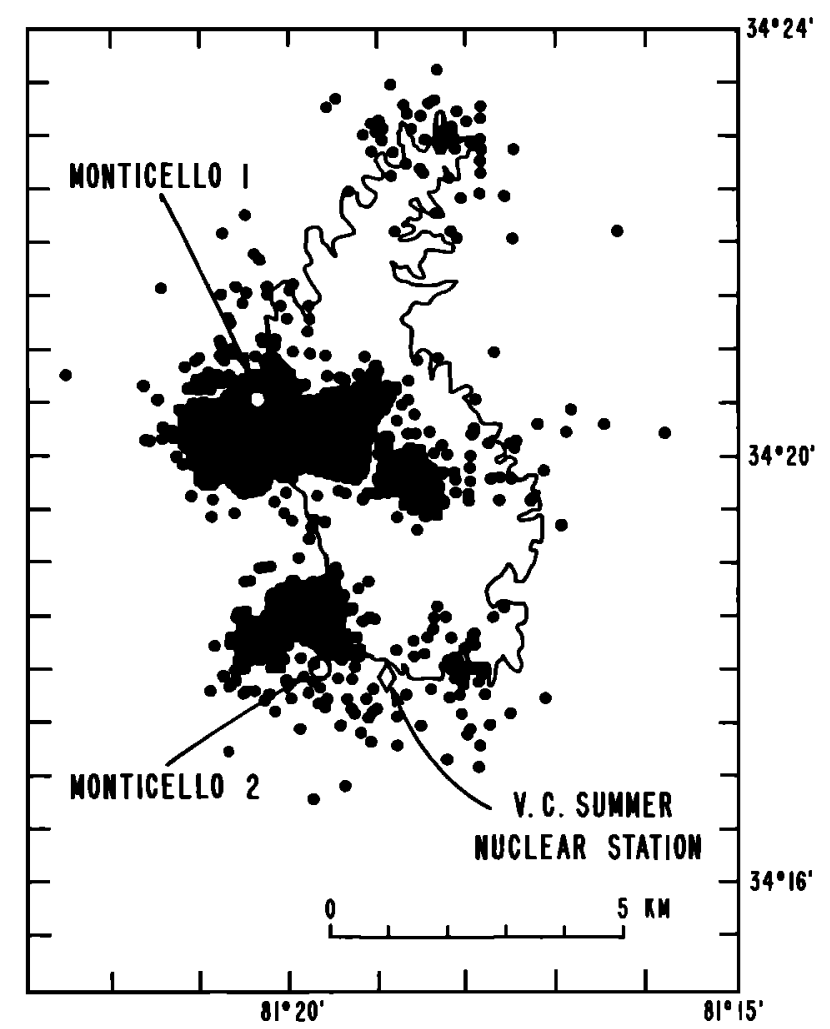

Fig. 3. Earthquake epicenters at Monticello Reservoir that occurred between December 1977 and September 1979 [after Talwani et al., 1980] and the location of wells Mont 1 and Mont 2. 
the pressure at which the already formed fracture opened at the well bore to accept fluid on the third pressurization cycle and set $T=0$ in (1) to compute $S_{H}$. Haimson [1978] and Enever and Wooltorton [1982] have found good results with this method in cases when $T$ was known and $S_{H}$ could be computed both ways. A more detailed rationale for this method is discussed by Hickman and Zoback [1982].

When the least principal stress is vertical, a vertical hydraulic fracture will form at the borehole when, as in the case of the measurements reported here, an inflatable straddle packer is used to isolate the fracture interval [see Haimson and Fairhurst, 1970]. As it propagates, however, the fracture will tend to turn into a horizontal plane, and as this occurs, the long-term shut-in pressure approaches the value of the vertical stress $S_{v}$ [Zoback et al., 1977, 1980].

The azimuth of the maximum horizontal principal stress coincides with the orientation of the hydraulic fracture at the well bore. After drilling each hole a careful survey was made with an ultrasonic borehole televiewer (described below) to locate intervals without natural fractures for the hydrofrac tests. The same tool was used to inspect the borehole after hydraulic fracturing to determine the orientation of the fracture and hence the azimuth of $S_{H}$. Unfortunately, no reliable hydrofrac orientations were obtained in either Mont 1 or Mont 2 because the televiewer was not successful in detecting the hydraulic fractures and attempts to use impression packers [see Anderson and Stahl, 1967] were unsuccessful due to an operational mishap.

\section{Results}

The results of the hydrofrac tests are summarized in Table 1 , and the data are presented and discussed at length in the appendix. The magnitudes of the least horizontal principal stress $S_{h}$ and the greatest horizontal principal stress $S_{H}$ are shown in Figures 4 and 5. Also shown in Figures 4 and 5 are the theoretical vertical stress $S_{v}$ (for an assumed density of
$2.7 \mathrm{~g} / \mathrm{cm}$ ), and a range of values at which the difference between $S_{H}$ and $S_{v}$ is sufficiently large so as to cause reverse faulting on any well-oriented planes that might exist. The latter values were arrived at in the following way: In accordance with the Coulomb failure criteria, frictional sliding will occur on preexisting faults at a critical ratio of the maximum and minimum effective principal stresses $S_{1}-P_{p}$ and $S_{3}-P_{p}$ (where $P_{p}$ is the pore pressure). Jaeger and Cook $[1969$, p. 98$]$ show that in the absence of cohesion, this ratio is

$$
\frac{S_{1}-P_{p}}{S_{3}-P_{p}}=\left[\left(\mu^{2}+1\right)^{1 / 2}+\mu\right]^{2}
$$

where $\mu$ is the coefficient of friction of the material. In terms of the principal stresses for the case of reverse faulting, the maximum horizontal principal compressive stress at failure $S_{H *}$ is expressed in terms of the vertical principal stress, $S_{v}$, $\boldsymbol{\mu}$, and $\boldsymbol{P}_{p}$ by

$$
S_{H *}=\left[\left(\mu^{2}+1\right)^{1 / 2}+\mu\right]^{2}\left(S_{v}-P_{p}\right)+P_{p}
$$

The hachured area in Figures 4 and 5 defines the magnitudes for $S_{H *}$ for incipient reserve faulting if $\mu$ is taken to be in the range 0.6-0.8 and cohension is assumed to be zero [after Byerlee, 1978], and $P_{p}$ is taken simply to be the hydrostatic pressure (which will be shown to be approximately correct). If $S_{h}$ is approximately equal to $S_{v}$, the hachured areas in Figures 4 and 5 also indicate the approximate critical range of values for $S_{H}$ at which strike slip faulting will occur if well-oriented vertical fault planes exist.

In Mont 1 (Figure 4) $S_{h}$ is greater than $S_{v}$ at shallow depth (165 m), and $S_{H}$ is at a critical value for reverse faulting. Between 165 and $728 \mathrm{~m}$ the stresses do not change much with depth; $S_{h}$ becomes less than $S_{v}$, and the difference between the three principal stresses is relatively small. With the exception of the measurement at $728 \mathrm{~m}$, the data indicate

\begin{tabular}{|c|c|c|c|c|c|c|c|c|c|}
\hline \multirow[b]{2}{*}{ Depth, m } & \multicolumn{4}{|c|}{ Hydrofracturing Data } & \multicolumn{4}{|c|}{ Principal Stresses } & \multirow[b]{2}{*}{ Comments } \\
\hline & $\begin{array}{c}\text { Breakdown } \\
\text { Pressure, } \\
\text { bars }\end{array}$ & $\begin{array}{l}\text { Shut-In/ } \\
\text { Pumping } \\
\text { Pressure, } \\
\text { bars }\end{array}$ & $\begin{array}{l}\text { Fracture } \\
\text { Opening } \\
\text { Pressure, } \\
\text { bars }\end{array}$ & $\begin{array}{c}\text { Hydrostatic } \\
\text { Pressure, } \\
\text { bars }\end{array}$ & $\begin{array}{c}\text { Minimum } \\
\text { Horizontal } \\
\text { Stress, } \\
\text { bars }\end{array}$ & $\begin{array}{l}\text { Maximum } \\
\text { Horizontal } \\
\text { Stress, } \\
\text { bars }\end{array}$ & $\begin{array}{c}\text { Vertical } \\
\text { Stress, } \\
\text { bars }\end{array}$ & $\begin{array}{c}\text { Tensile } \\
\text { Strength, } \\
\text { bars }\end{array}$ & \\
\hline \multicolumn{10}{|c|}{ Monticello 2} \\
\hline 97 & 110 & $34 \pm 2$ & $48 \pm 3$ & 10 & $34 \pm 2$ & $44 \pm 9$ & 26 & $62 \pm 3$ & $\begin{array}{l}\text { repeatable shut-in and pumping } \\
\text { pressures although from the final } \\
\text { shut-in pressure fracture probably } \\
\text { rotated into a horizontal plane } \\
\text { (see appendix) }\end{array}$ \\
\hline 128 & 179 & $36 \pm 2$ & $50 \pm 3$ & 13 & $36 \pm 2$ & $45 \pm 9$ & 34 & $129 \pm 3$ & \\
\hline 205 & 191 & $47 \pm 2$ & $62 \pm 3$ & 21 & $47 \pm 2$ & $58 \pm 9$ & 54 & $129 \pm 3$ & \\
\hline 298 & 211 & $56 \pm 2$ & $63 \pm 3$ & 30 & $56 \pm 2$ & $75 \pm 9$ & 79 & $148 \pm 3$ & \\
\hline 312 & 218 & $64 \pm 2$ & $66 \pm 3$ & 31 & $64 \pm 2$ & $95 \pm 9$ & 83 & $152 \pm 3$ & \\
\hline 400 & 105 & $87 \pm 2$ & $79 \pm 3$ & 40 & $87 \pm 2$ & $142 \pm 9$ & 106 & $26 \pm 3$ & unusually low tensile strength \\
\hline 646 & 232 & $166 \pm 2$ & $129 \pm 3$ & 64 & $166 \pm 2$ & $305 \pm 9$ & 171 & $103 \pm 3$ & \\
\hline \multicolumn{10}{|c|}{ Monticello 1} \\
\hline 165 & 170 & $79 \pm 2$ & $85 \pm 3$ & 17 & $79 \pm 2$ & $135 \pm 9$ & 44 & $85 \pm 3$ & \\
\hline 486 & 179 & $119 \pm 2$ & $115 \pm 3$ & 49 & $119 \pm 2$ & $193 \pm 9$ & 129 & $64 \pm 3$ & \\
\hline 728 & 196 & $119 \pm 2$ & $111 \pm 3$ & 73 & $119 \pm 2$ & $173 \pm 9$ & 193 & $85 \pm 3$ & \\
\hline 961 & 266 & $186 \pm 2$ & $144 \pm 7$ & 97 & $186 \pm 2$ & $317 \pm 13$ & 255 & $122 \pm 7$ & $\begin{array}{l}\text { unusually large uncertainty in } \\
\text { fracture opening pressure and, } \\
\text { therefore, in } S_{H} \text { is due to } \\
\text { gradual pressurization during } \\
\text { cycles } 3-5 \text { (see appendix) }\end{array}$ \\
\hline
\end{tabular}

TABLE 1. Summary of Stress Measurements

*Calculated for the appropriate density and depth. 


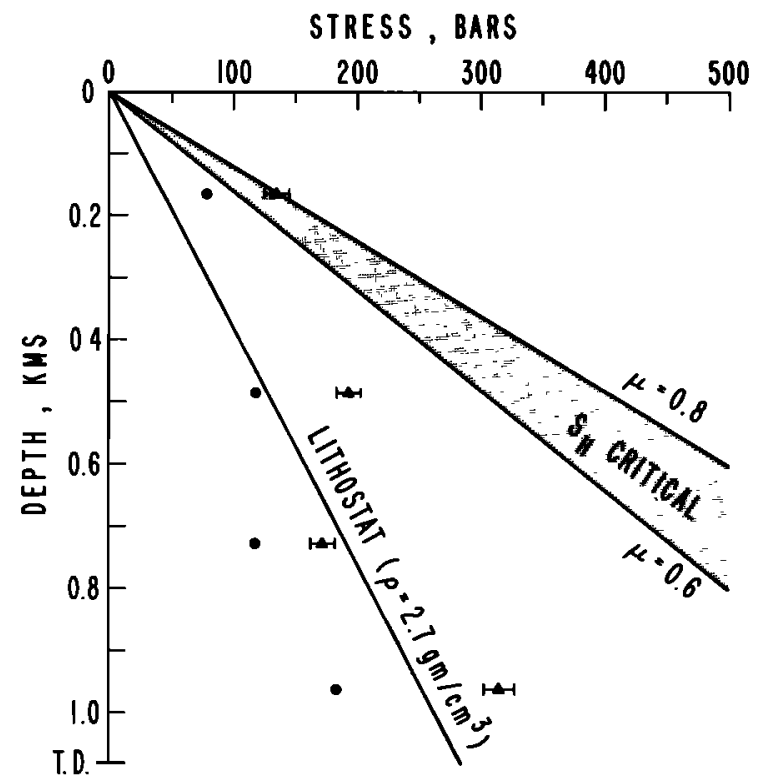

Fig. 4. Hydraulic fracturing stress measurements as a function of depth in Mont 1. Dots indicate the magnitude of the least horizontal principal compressive stress $S_{h}$, and the triangle indicates the magnitude of $S_{H}$, the greatest horizontal principal compressive stress. The zone labeled $S_{H}$ critical indicates the magnitude of $S_{H}$ at which reverse faulting is expected on well-oriented fault planes for coefficients of friction between 0.6 and 0.8 (see text).

a moderate linear increase in $S_{h}$ and $S_{H}$ with depth. In Mont 1 , only the data at $165 \mathrm{~m}$ indicate conditions in which the difference between principal stresses is anywhere close to that required for failure.

In Mont 2 (Figure 5) the results are generally similar to those in Mont 1. At depths less than $150 \mathrm{~m}, S_{h}$ is slightly greater than $S_{v}$, and at depths greater than $150 \mathrm{~m}, S_{h}$ is slightly less. At depths less than $200 \mathrm{~m}$ there is very little change of $S_{H}$ with depth. Although at $97 \mathrm{~m}, S_{H}$ is near its critical value for incipient reverse faulting on well-oriented planes, from about 100 - to $300-\mathrm{m}$ depth there is very little difference between the three principal stresses. Below 300 $\mathrm{m}, S_{H}$ seems to increase fairly rapidly with depth, and at 646 $\mathrm{m}, S_{H}$ is within about $\mathbf{1 0 0}$ bars of its critical value. It is not known if this apparent increase in $S_{H}$ with depth can be extrapolated to depths greater than $650 \mathrm{~m}$. We were not able to fracture hydraulically the formation at depths greater than $650 \mathrm{~m}$ at the maximum borehole pressure attainable (at 1090 $\mathrm{m}$, for example, a pressure of 412 bars did not cause a hydraulic fracture). This suggests that the difference between $S_{H}$ and $S_{h}$ does not increase rapidly with depth because this would result in a lower breakdown pressure than at $650 \mathrm{~m}$ rather than a higher one if the tensile strength was about the same (see equation (1)). This argument can be used to estimate roughly an upper limit value of $S_{H}$ at 1090 m. If $S_{h} \simeq 280$ bars and $T \leq 150$ bars, then $S_{H} \leq 470$ bars (equation (1)), a value well below the critical value.

\section{Discussion}

The stress measurements at $165 \mathrm{~m}$ in Mont 1 and $97 \mathrm{~m}$ in Mont 2 indicate that if well-oriented fault planes exist in the upper few hundred meters, ambient conditions are such that a small pertubation of the pore pressure could reasonably be expected to cause reverse faulting. This result is generally consistent with the shallow depths of the earthquakes and the focal plane mechanisms which indicate primarily reverse faulting. In the following section we will investigate whether well-oriented fault planes do, in fact, exist and whether a change in subsurface pore pressure can be demonstrated to have occurred. At this point, however, several issues should be discussed further: the depth to which earthquakes might be expected based on the stress measurements, and whether there may have been a change in stress before the stress measurements were made due to the stress drops of earthquakes that occurred in the vicinity of the wells.

Before we address the question of earthquake depth, let us consider the issue of stress drops because it could conceivably have affected the stress measurements. In studying several Monticello earthquakes P. D. Talwani (personal communication, 1981) and Fletcher [this issue] found values of the drop in shear stress $(\Delta \tau)$ ranging up to several tens of bars. This is consistent with the results of Hanks [1977], who compiled stress drop data for many earthquakes and found that they range from 1 to 100 bars. The maximum shear stress $\tau$ is given by

$$
\tau \simeq 1 / 2\left(S_{1}-S_{3}\right)
$$

Because in the case of reverse faulting $S_{3}=S_{v}, S_{1}=S_{H}$, and $S_{3}\left(S_{v}\right)$ is constant, the difference between $S_{H}$ before and after an earthquake, $\Delta S_{H}$, is simply twice the stress drop $\Delta \tau$ or

$$
\Delta S_{H} \simeq 2 \Delta \tau \leq 100 \text { bars }
$$

for even the largest stress drop earthquakes. Thus it is possible that $S_{H}$ could have been up to about 100 bars higher than the measured value if an earthquake occurred very close to the well prior to the time of the measurement. If this were the case, then the data in Figures 4 and 5 indicate that

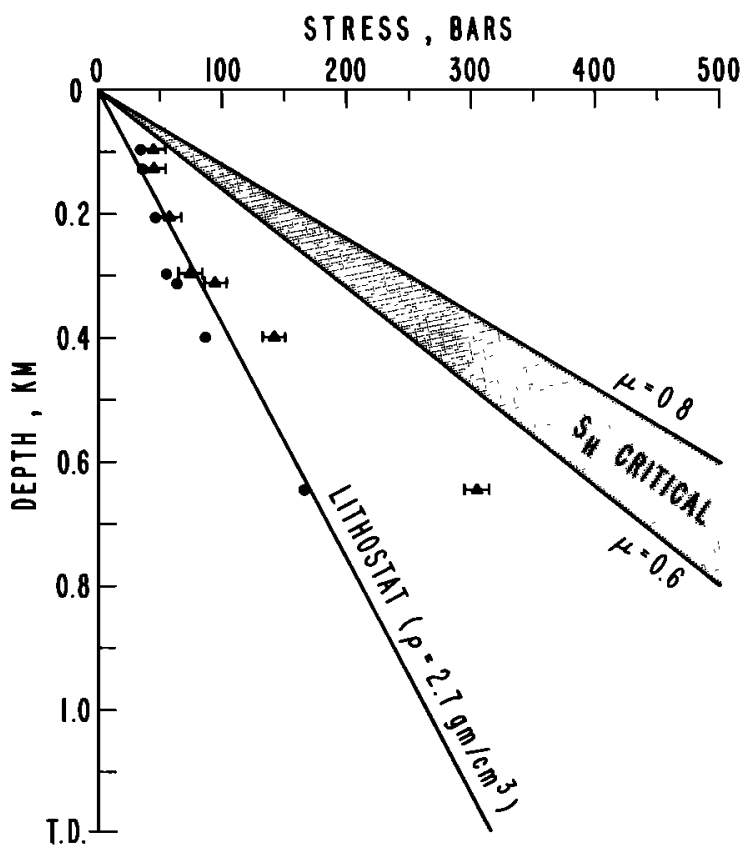

Fig. 5. Hydraulic fracturing stress measurements as a function of depth in Mont 2. Dots indicate the magnitude of the least horizontal principal compressive stress $S_{h}$, and the triangle indicates the magnitude of $S_{H}$, the greatest horizontal principal compressive stress. The zone labeled $S_{H}$ critical indicates the magnitude of $S_{H}$ at which reverse faulting is expected on well-oriented fault planes for coefficients of friction between 0.6 and 0.8 (see text). 
the maximum earthquake focal depth at Mont 1 is about 500 $\mathrm{m}$, while the maximum focal depth at Mont 2 is about 600 $700 \mathrm{~m}$ if the limiting stress estimated for a depth of $1095 \mathrm{~m}$ in Mont 2 ( $S_{H} \leq 470$ bars) is approximately correct.

This depth estimate compares fairly well with the seismicity data, but deeper earthquakes also appear to be occurring. In 5 months of the most accurately located data listed by Talwani et al. [1980], 81\% of the highest quality events had focal depths of $1 \mathrm{~km}$ or less, but the average depth uncertainty (parameter ERZ in the program HYP071 by Lee and Lahr [1972]) for these events was $0.7 \mathrm{~km}$. ERZ is the minimum uncertainty of the focal depth because it assumes that the velocity model is correct and the error in location is attributed primarily to the station spacing of the seismic network and timing errors. Thus due to the large ERZ and because uncertainty in the applicability of a single velocity model in such heterogeneous terrain further limits resolution of focal depth, the earthquake depths of Talwani et al. [1980] are probably not of sufficient accuracy to be compared with the maximum depth estimate suggested by the stress measurements. However, taking the focal depth data at face value, the maximum earthquake depths are about $2 \mathrm{~km}$ [Talwani et al., 1980]. (Fletcher [this issue] calculated focal depths ranging between $100 \mathrm{~m}$ and $1.4 \mathrm{~km}$ for events near Mont 1 and estimated a typical vertical location accuracy of 300-500 m.) If so, then it follows that in some areas around the reservoir, either $S_{H}$ is closer to the failure condition at greater depth than we observed in either well or stress drops occurred in close proximity to the wells that were appreciably larger than a few tens of bars. In either case, the maximum depth to which faulting would be expected based on the in situ stress measurements would be more in agreement with the seismically determined focal depths.

\section{Fault Planes}

The arguments presented in the preceding section were based on the assumption that well-oriented fracture planes exist for reverse slip to take place at shallow depth. To examine the in situ state of fracturing, an extensive survey of each well was done with an ultrasonic borehold televiewer, the results of which are described in detail by Seeburger and Zoback [1982] and are summarized below.

\section{Method}

To summarize the operation of the televiewer briefly (see Zemaneck et al. [1970] for a detailed discussion), an acoustic transducer with a fundamental frequency of $2 \mathrm{MHz}$ rotates with a speed of three revolutions per second as it is moved vertically in the well at a rate of $2.5 \mathrm{~cm} / \mathrm{s}$. The transducer emits a $3^{\circ}$ focused beam 180 times per second. The amplitude of the acoustic pulse that is reflected off the borehole wall is displayed as intensity, or brightness, on a three-axis oscilloscope as a function of the beam azimuth and vertical position in the hole, and the images are recorded on both film and video tape. The data are oriented with respect to magnetic north by a flux gate magnetometer in the tool. Essentially, the smoothness of the borehole wall is portrayed in the borehole televiewer images. Where the borehole wall is perturbed by a planar feature such as a fracture, a dark sinusoidal pattern is seen in the images. Resolution of the tool depends upon hole diameter, wall conditions, reflectivity of the formation, and acoustic impedance of the well bore fluid. The wall condition is the most important factor, as a rough well bore makes detection of fine features quite difficult. Except for highly fractured intervals, the conditions in the Monticello wells were good, and all fractures with apertures of more than a few millimeters were probably detected. In heavily fractured intervals, however, only a fraction of the total fracture population could be detected.

Knowing the well diameter, the dip of the fractures may be calculated by measuring the peak to trough amplitude of the sinusoids. The fracture strike is taken to be in the direction of the midpoint between peak and trough. The test wells were drilled with a diameter of approximately $15 \mathrm{~cm}$ so that the circumference (horizontal scale) is about $50 \mathrm{~cm}$. Thus there is greater than 3:1 horizontal exaggeration in the pictures. As a result of the horizontal exaggeration, fractures with dips of less than $5^{\circ}$ appear to be horizontal. Only those features in the records for which the sinusoidal signature could be resolved were picked as dipping fractures. Televiewer surveys were run in each well from total depth (TD) to the top of the water column or the bottom of the casing which was very near the surface.

\section{Results}

The data (Figures 6-8) show that the state of natural fracturing in the two wells is not very similar. First, the total number of fractures in Mont 2 is approximately 2 times that in Mont 1 (Figure 6c). Fractures in Mont 1 were found to occur mostly in discrete intervals separated by relatively unfractured rock (Figure $6 a$ ). There does not seem to be a concentration of fractures near the surface. In contrast, the granodiorite encountered in Mont 2 was highly fractured, particularly from the surface to about $275 \mathrm{~m}$ and from about 460 to $510 \mathrm{~m}$. Most of the fractures were found to be dipping, but 26 of the 147 fractures in Mont 1 and 65 of the 430 fractures in Mont 2 were subhorizontal. About half of the horizontal fractures were found in the upper $300 \mathrm{~m}$ of each well, although in both wells several horizontal fractures were found at depths greater than $1 \mathrm{~km}$.

Lower hemisphere stereographic projections of fracture poles (Figures 7 and 8) show that fractures with a wide range of orientations are present and that, as with fracture density, the fracture orientations in the two wells are quite different. In Mont 2 (Figure 7) the fractures at depths less than $305 \mathrm{~m}$ form two significant clusters; the cluster striking approximately north-south and dipping steeply to the east predominates, but another cluster of fractures is observed that strikes east-northeast and dips gently to the southeast. In the lower interval (610 $\mathrm{m}$ to TD) the dense cluster of fractures striking north-south and dipping steeply to the east is again predominant. Interestingly, in the interval from 305 to $610 \mathrm{~m}$ the most significant fracture cluster has a strike which differs by about $60^{\circ}$ from that found in the rest of the hole. This group of fractures is west-northwest trending and northeast dipping (Figure 7), and it is largely concentrated between 450 and $500 \mathrm{~m}$ depth (Figure 6). In the upper zone of Mont 1 (surface-305 m) the fracture cluster with northwest strike and southwest dip is most apparent (Figure 8). In the middle zone of Mont $1(305-610 \mathrm{~m})$ the fracture cluster with northeast strike and southeast dip is most apparent. In the bottom third of Mont 1 (610 m-TD), the fracture distribution is essentially random.

Secor [1980] made joint studies at surface outcrops near Monticello Reservoir. At outcrops within a few kilometers of 


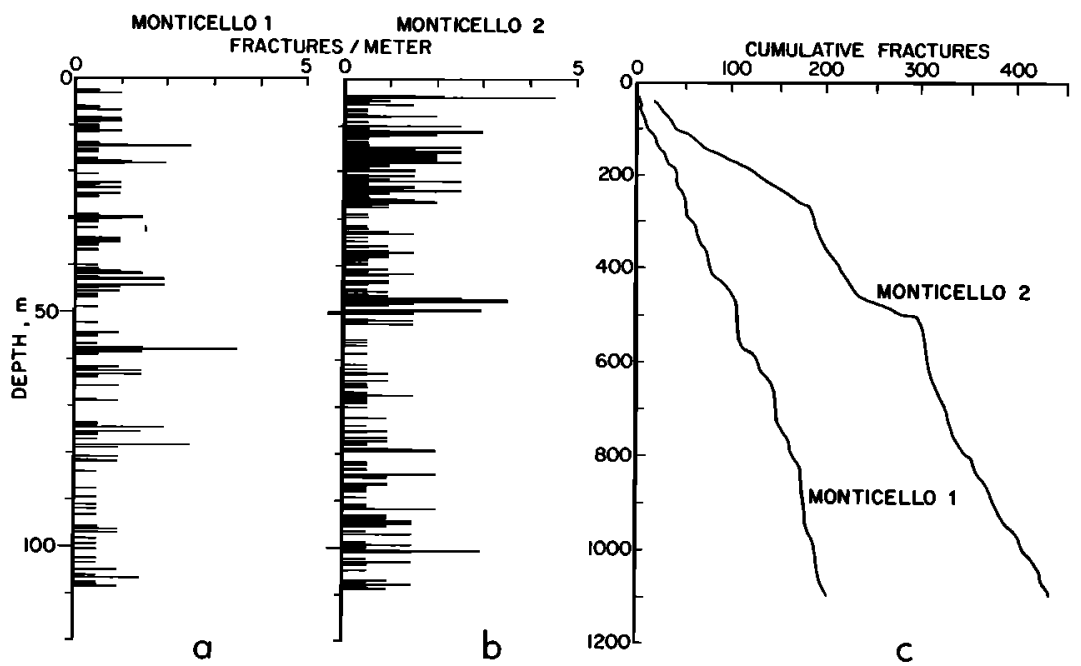

Fig. 6. The frequency of observable fractures in wells Mont 1 and Mont 2.

the well sites, fracture distributions similar to those in both Mont 1 and Mont 2 were found, but Secor concluded that there was little regional consistency to the orientation of the major joint sets. The marked difference we have observed in the two wells seems to support his conclusion. Surface fractures were also studied on the cleared bedrock surface at the site of the Virgil C. Summer Nuclear Power Station, which is near Mont 2 (Figure $1 b$ ). A total of 247 fractures with no observed shear displacement across their faces and 85 fractures that exhibited either shear displacement or hydrothermal alteration were examined [Dames and Moore, 1974]. In both cases, a pole density maximum occurred for planes striking about $\mathrm{N} 44^{\circ} \mathrm{E}$, dipping more than $60^{\circ} \mathrm{SE}$. The orientation is very similar to some of the shallow fractures found in Mont 1. However, other maxima in the surface data, such as a northeast trending, northwest dipping set, are not apparent in data from either well, and there is no surface indication of the pronounced north-south trending, eastward dipping set of fractures which is found in Mont 2.

\section{Discussion}

The borehole televiewer data demonstrate that the existing fractures have a wide range of orientations that could serve as potential fault planes. The shallow depths of the

\section{MONTICELLO 2}

a)

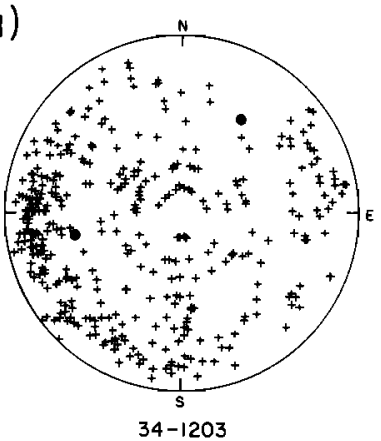

C)

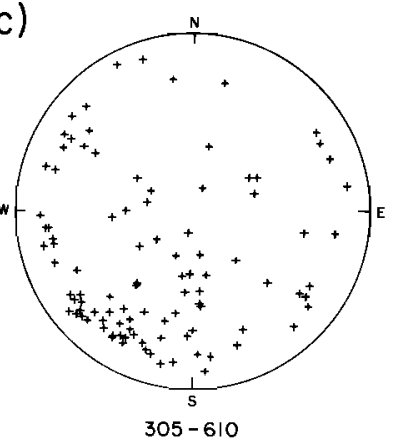

b)

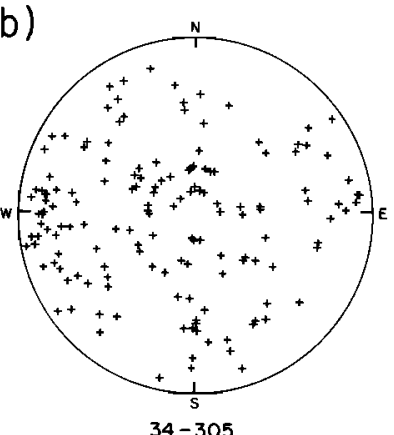

d)

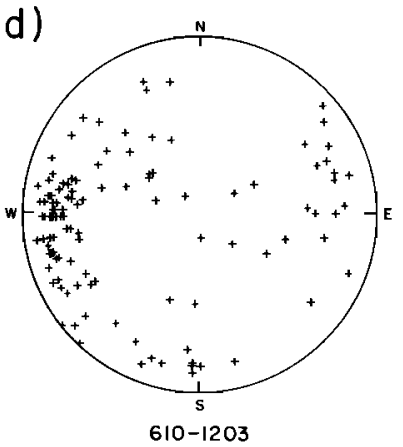

Fig. 7. Lower hemisphere stereographic projection of fracture poles in Mont 2. Solid dots indicate nodal planes determined by focal mechanism studies of nearby earthquakes (P. Talwani, written communication, 19XX)

\section{MONTICELLO I}

a)

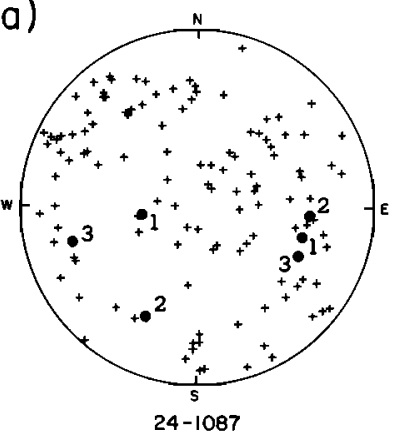

c)

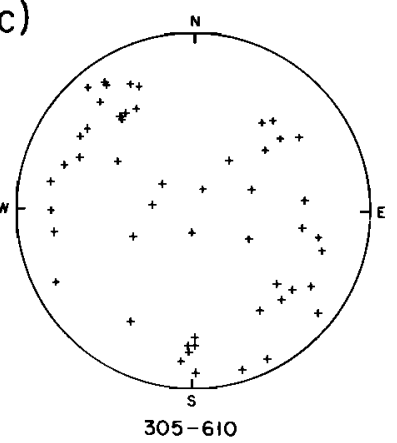

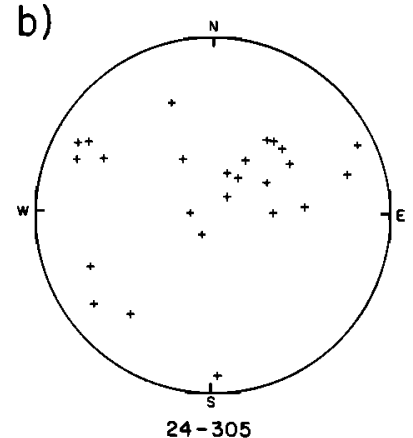

b)

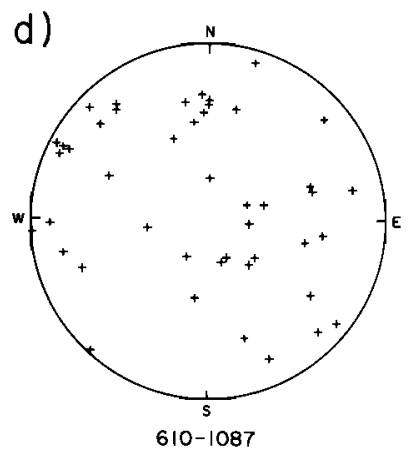

Fig. 8. Lower hemisphere stereographic projection of fracture poles in Mont 1 . Solid dots labeled 1, 2, and 3 indicate nodal planes determined for three different composite focal mechanisms for nearby earthquakes (P. Talwani, written communication, 1981). 
earthquakes and the manner in which the earthquakes cluster (rather than defining linear fault planes) seem to suggest that the multitude of fractures observed in the well could be representative of the earthquake fault planes. Furthermore, the substantial apparent width of the fractures (many exceed $1 \mathrm{~cm}$ ) and the persistence of these fractures with depth suggest that they have undergone shear displacement that generated zones of fault gouge.

In Figures $7 a$ and $8 a$ we compare the fracture data with poles to fault planes determined from composite focal plane mechanisms (P. Talwani, written communication, 1981) for earthquakes occurring near each of the wells. The composite earthquake focal mechanism for earthquakes near Mont 2 yields nodal planes that strike $\mathrm{N} 12^{\circ} \mathrm{W}$ and $\mathrm{N} 56^{\circ} \mathrm{W}$ and dip $50^{\circ} \mathrm{E}$ and $50^{\circ} \mathrm{SW}$, respectively. The poles to these planes are plotted in Figure $7 a$ for comparison to the fracture data. Within the uncertainty of the data, it is seen that the $\mathrm{N} 12^{\circ} \mathrm{W}$, $50^{\circ} \mathrm{E}$ focal plane is in very good agreement with the numerous N-S striking, east dipping fracture planes. This good correlation suggests that shallow reverse slip motion on $\sim \mathrm{N}$ $\mathrm{S}$ striking, steeply east dipping fault planes is responsible for the earthquakes in the southwest section of the reservoir. Although the close association between the intense zone of fracturing near $500 \mathrm{~m}$ and a high pore pressure zone (see below) seems quite striking, most of the fractures between 305 and $610 \mathrm{~m}$ do not have the N-S strike and east dip that characterizes the rest of the well and the focal plane mechanisms. Thus this intense fracture zone does not seem to be a more likely source zone for earthquakes than others in the well.

Just as the orientation and density of fracture planes at Mont 1 are different than those at Mont 2, the composite earthquake focal plane mechanisms for nearby events are also different and three different sets of nodal planes were found ( $P$. Talwani, written communication, 1981). The planes yielded by the focal mechanisms are shown in Figure $8 a$, and one plane from each mechanism usually falls near available fractures. Perhaps because there is no dominating fracture set in the well, it is not straightforward to associate particular nodal planes with certain fractures. However, it may be significant that an approximately NNE striking, west dipping plane is nearly common to all three focal mechanisms.

The borehole televiewer data suggest that some of the fractures observed in the wells might possibly be the fault planes involved in the earthquakes. In the case of Mont 2, the persistence of fractures at depth with apparent widths of up to several centimeters suggests that shear motion has occurred on the fracture planes, and analysis of core and cuttings from both wells shows that the fracture zones have apparently undergone shear displacement during their history (D. Prowell, personal communication, 1981).

\section{Pore Pressure Measurements}

To establish whether or not there has been a change in subsurface pore pressure resulting from reservoir impoundment, a series of downhole tests were performed in each well. Information on preimpoundment subsurface pore pressure in the vicinity of Monticello Reservoir comes from a series of shallow holes near the power plant site and from scattered shallow holes located around the periphery of the reservoir. Before discussion of these tests, it is important to consider the surface elevation of each well, local topogra- phy, and other possible constraints on the preimpoundment pore pressure at depth.

As shown in Figure $1 b$, Mont 1 was drilled at an elevation of $157.9 \mathrm{~m}$ on a ridge adjacent to Monticello Reservoir (which has a mean water elevation of $129.5 \mathrm{~m}$ ). The surface elevation of the well is $28.4 \mathrm{~m}$ higher than the reservoir and $78.7 \mathrm{~m}$ higher than the elevation of the Broad River (elevation $79.3 \mathrm{~m}$ ), which has been at nearly the same level since it was dammed in the 1950's. However, at an elevation of 106.7 $\mathrm{m}$, the ground surface at Mont 2 is $22.8 \mathrm{~m}$ below the reservoir level and $27.4 \mathrm{~m}$ above the level of Broad River. Before impoundment of Monticello Reservoir, it was commonly assumed that groundwater occurred under water table conditions with local recharge primarily occurring through surface infiltration [South Carolina Electric and Gas, 1977]. Near the site of the power plant the preimpoundment water table followed topography at an average depth of about $14 \mathrm{~m}$ [South Carolina Electric and Gas, 1977, 1980]. We assume that the same situation existed nearby at the site of Mont 2. Near Mont 1, a shallow observation well, which is about 0.5 $\mathrm{km}$ away and at about the same elevation, indicated that the water table was about $21 \mathrm{~m}$ below the ground surface before impoundment [South Carolina Electric and Gas, 1980].

\section{Method}

Subsurface pore pressure estimates were made in three different ways. First, when major fractures were encountered during drilling the rapid in-flow of water shut off the percussion air hammer used to drill the wells. The depth at which this occurred and the height to which water rose in the well were noted. Because the pore pressure did not have much time to equilibrate before an observation, this method was useful only when extremely permeable fracture systems were encountered. The other methods used to estimate pore pressure involved setting a hydraulic packer at a certain elevation in the well and allowing the fluid column in the pipe to approach equilibrium. This is intended to yield the pore pressure beneath the packer, although we may, in fact, be observing the pore pressure in only the more permeable fracture zones below the packer. As explained in Table 2, equilibrium was reached in some cases but in other cases the pore pressure could only be estimated within certain bounds. In still other cases the pore pressure at equilibration was estimated by extrapolating a plot of pressure $p$ as a function of pumping time $t$ and shut-in time $\Delta t$ following water injection under steady state conditions. This $p$ versus $(t+$ $\Delta t$ )/ $\Delta t$ method [Mathews and Russell, 1967] was used only for two tests in Mont 2.

\section{Results}

For the purpose of presentation the pore pressure data have been reduced to the elevation of lowest reasonable datum, that of the Broad River. Thus relative pressure $P_{r}$ in Table 2 and Figures 9 and 10 refers to the subsurface pressure in excess of that which would exist if the water table were at the elevation of the Broad River. That is,

$$
P_{r}=P_{\mathrm{ob}}-\rho g z_{b}
$$

where $\boldsymbol{P}_{\mathrm{ob}}$ is the observed pore pressure, $\rho$ is the density of water, $g$ is gravitational acceleration, and $z_{b}$ is depth below the elevation of the Broad River.

Straight vertical lines in Figures 9 and 10 represent pore pressure under water table conditions for a given elevation, 
TABLE 2. Summary of Pore Pressure Measurements

\begin{tabular}{|c|c|c|}
\hline Depth, m & $\begin{array}{c}\text { Relative } \\
\text { Pressure*, } \\
\text { bars }\end{array}$ & Comments \\
\hline $\begin{array}{r}65 \\
100 \\
385 \\
480 \\
491 \\
640 \\
734\end{array}$ & $\begin{array}{l}4.1 \\
4.1 \\
2.7 \\
2.4 \\
2.2 \\
2.4 \\
2.3\end{array}$ & $\begin{array}{l}\text { Mont } 1 \\
\text { head measured during drilling } \\
\text { head measured during drilling } \\
\text { Packer test, equilibration assumed } \\
\text { Packer test, equilibration assumed } \\
\text { head measured during drilling } \\
\text { Packer test, equilibration assumed } \\
\text { Packer test, equilibration assumed }\end{array}$ \\
\hline $\begin{array}{r}95 \\
101 \\
280 \\
365 \\
490 \\
625 \\
722\end{array}$ & $\begin{array}{r}2.0 \\
2.2 \\
4.0 \\
4.1 \\
<2.9 \\
<2.9 \\
1.6\end{array}$ & $\begin{array}{l}\text { Mont } 2 \\
\text { Packer test, fast equilibration } \\
\text { Packer test, extrapolated } \\
\text { Packer test, extrapolated } \\
\text { Packer test, equilibration assumed } \\
\text { Packer test, unequilibrated } \\
\text { Packer test, unequilibrated } \\
\text { Packer test, equilibration assumed }\end{array}$ \\
\hline
\end{tabular}

*Relative to Broad River datum (see text).

and the position of the vertical line along the $\boldsymbol{P}_{r}$ axis is controlled by the difference between the given elevation and that of the Broad River. The depth data in Figures 9 and 10 are also reduced to depth below the Broad River. For reference, the relative elevation of the drill site, Monticello Reservoir, and the Broad River are shown in each figure as well as the location of the fractures identified in the well which were discussed previously.

As shown in Figure 9, at Mont 1 the approximate elevation of the preimpoundment water table was slightly higher than the reservoir hydrostat. This implies that if the subsurface pore pressure was occurring under water table conditions, no appreciable change in subsurface pore pressure would result from reservoir impoundment. However, the pore pressure measurements made in Mont 1 suggest that the preimpoundment water table observed at $21-\mathrm{m}$ depth was actually a perched water table and the pore pressure at greater depth could have increased due to impoundment. The five pore pressure measurements below about $400 \mathrm{~m}$ all indicate a water table about $30 \mathrm{~m}$ lower than that expected on the basis of the nearby shallow well. At depths less than $100 \mathrm{~m}$, the subsurface pore pressure was much closer to the expected value but still below that expected. Thus it appears that near Mont 1, the aquifer at depths greater than a few hundred meters was relatively underpressured by at least a few bars before impoundment. Unfortunately, lacking preimpoundment pore pressure data from depth, we do not know how much the pore pressure observed in Mont 1 may have changed since impoundment.

The measurements in well Mont 2 (Figure 10) also indicate that the reservoir may have increased subsurface pore pressure. The pore pressure at depths of about $300-400 \mathrm{~m}$ was found to be high enough to result in artesian flow from the well. Because the surface elevation of the well is below that of the reservoir, a hydraulic connection between the reservoir and the well at depth could result in artesian flow. The artesian zone is apparently limited to the dense fracture zone which extends from about $400-500 \mathrm{~m}$. It appears that this fracture zone is quite permeable and in direct contact with the reservoir. At depths of about $100 \mathrm{~m}$, the pore pressure is only about 0.8 bars from the expected approximate preimpoundment pore pressure. Just below the arte- sian zone, the subsurface pore pressure is not accurately known because the pore pressure did not equilibrate during the measurements due to the low permeability (discussed below). As indicated in Figure 10, however, in general, the pore pressure is apparently between the preimpoundment level and the site hydrostat, and the pressure at the deepest measurement, $751 \mathrm{~m}$, has apparently not changed since impoundment.

\section{Discussion}

The zone of anomalously high pore pressure observed in Mont 2 demonstrates that permeable fracture systems extend to seismogenic depths. The diffusion of pore pressure to depth through such fracture zones is obviously an important element in the triggering of the seismicity. The most likely explanation of the artesian pressure encountered in Mont 2 is that the fracture zone found at $400-500 \mathrm{~m}$ depth (Figure 10) is in direct hydrologic communication with the reservoir because the reservoir is the nearest source of excess pore pressure. However, it is possible that this fracture system is not in hydrologic communication with the reservoir, but with permeable fracture zones that crop-out at an appropriately higher elevation. If this is the case, though it does not seem likely, then the pore pressure data from Mont 2 only demonstrate the manner in which impoundment of the reservoir could have caused an increase of pore pressure at depth.

Similarly, the observation that there is a perched water table at Mont 1 only demonstrates that it was possible for the subsurface pore pressure to have changed. The lack of preimpoundment data from depth makes it impossible to say whether it occurred or not. However, the discovery of the perched water table may enable us to explain an apparent enigma. That is, if the subsurface pore pressure near Monticello Reservoir simply resulted from normal water table conditions and if the water table followed the topography at a depth usually less than $20 \mathrm{~m}$, it would have been very difficult for earthquakes to be triggered by subsurface pore pressure changes in the regions adjacent to the reservoir where the elevation is more than $20 \mathrm{~m}$ higher than the reservoir level. As the pore pressure at depths greater than $300 \mathrm{~m}$ in Mont 1 is subhydrostatic, it does not matter that the near-surface water table is at about the same level as the reservoir water table; deeper pore pressure changes could have occurred.

\section{Permeability Measurements}

The rate at which pore pressure responds at depth to the impoundment of the reservoir is a function of the permeability of the rock. Theoretical studies [Bell and Nur, 1978; Withers and Nyland, 1978] have considered the subsurface change in pore pressure due to reservoir impoundment. It is important to know the in situ permeability at Monticello Reservoir to compare the theoretical fluid diffusion time with the time history of seismicity so as to provide an additional test of our working hypothesis. Moreover, if the working hypothesis is correct, knowing the in situ permeability allows us to predict the growth of the zone in which pore pressure has been perturbed with time.

\section{Method}

The basic technique employed for measuring permeability was the 'slug test' method described by Cooper et al. [1967] 


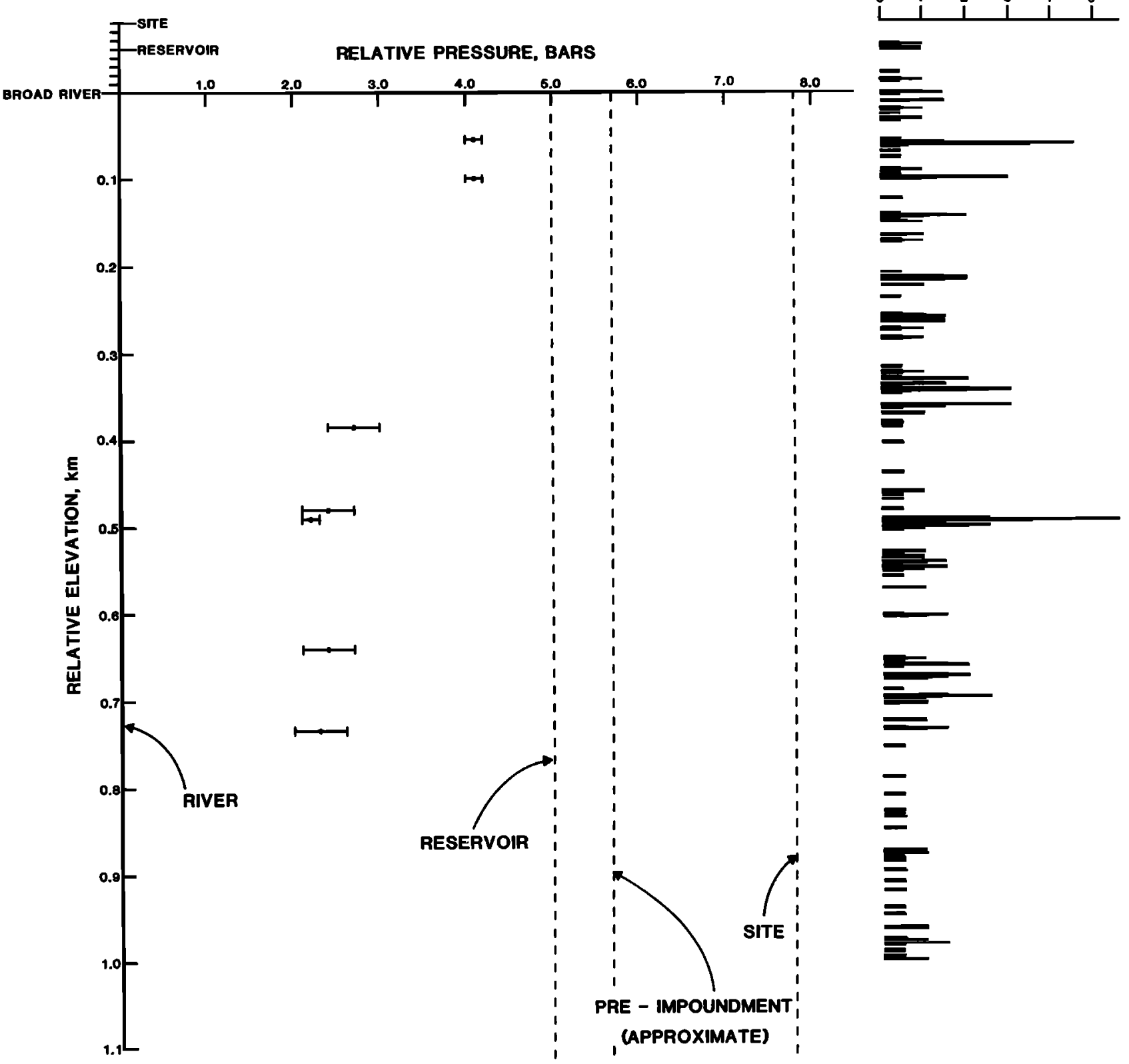

Fig. 9. Relative pore pressure in Mont 1 referenced to the elevation of the Broad River and the pore pressure appropriate to a water table at that depth. In the upper left-hand corner of the figure the relative elevation of the river, reservoir, and drill site are shown. Straight vertical lines in the figure represent pore pressure under water table conditions for the indicated elevation. At the right edge of the figure are the fracture densities observed in Figure $6 a$ appropriately shifted for depth.

and Bredehoeft and Papadopoulus [1980]. The slug test method consists of setting a single inflatable packer in the hole and subjecting the entire length of the hole below the packer to a nearly instantaneous pressure pulse or slug. The decay of the pressure pulse is then analyzed to determine the transmissivity of the tested interval. As transmissivity is simply the product of the permeability and the length of the tested interval, a bulk permeability for the interval below the packer can be calculated. The validity of assigning a bulk permeability to fractured rock (permeability is usually considered to be a property of a uniform, homogenous, and isotropic medium) has been discussed by Parsons [1966] and Barenblatt et al. [1960]. By comparing tests with the packer set at various depths in the hole, bulk permeability can be computed for various discrete intervals in the well by differencing the transmissivity values at the measurement depths. However, the uncertainty in such values is high as it is the sum of the uncertainties of the individual tests.

\section{Results}

Bulk permeability was determined for four intervals in Mont 2 and one interval in Mont 1 (Figure 11). The measurements reported below are discussed in detail by S. Hickman and M. D. Zoback (manuscript in preparation, 1982) and are summarized here. The three test intervals between 112 and $539 \mathrm{~m}$ in Mont 2 and the 726 to $1086 \mathrm{~m}$ (total depth) interval 


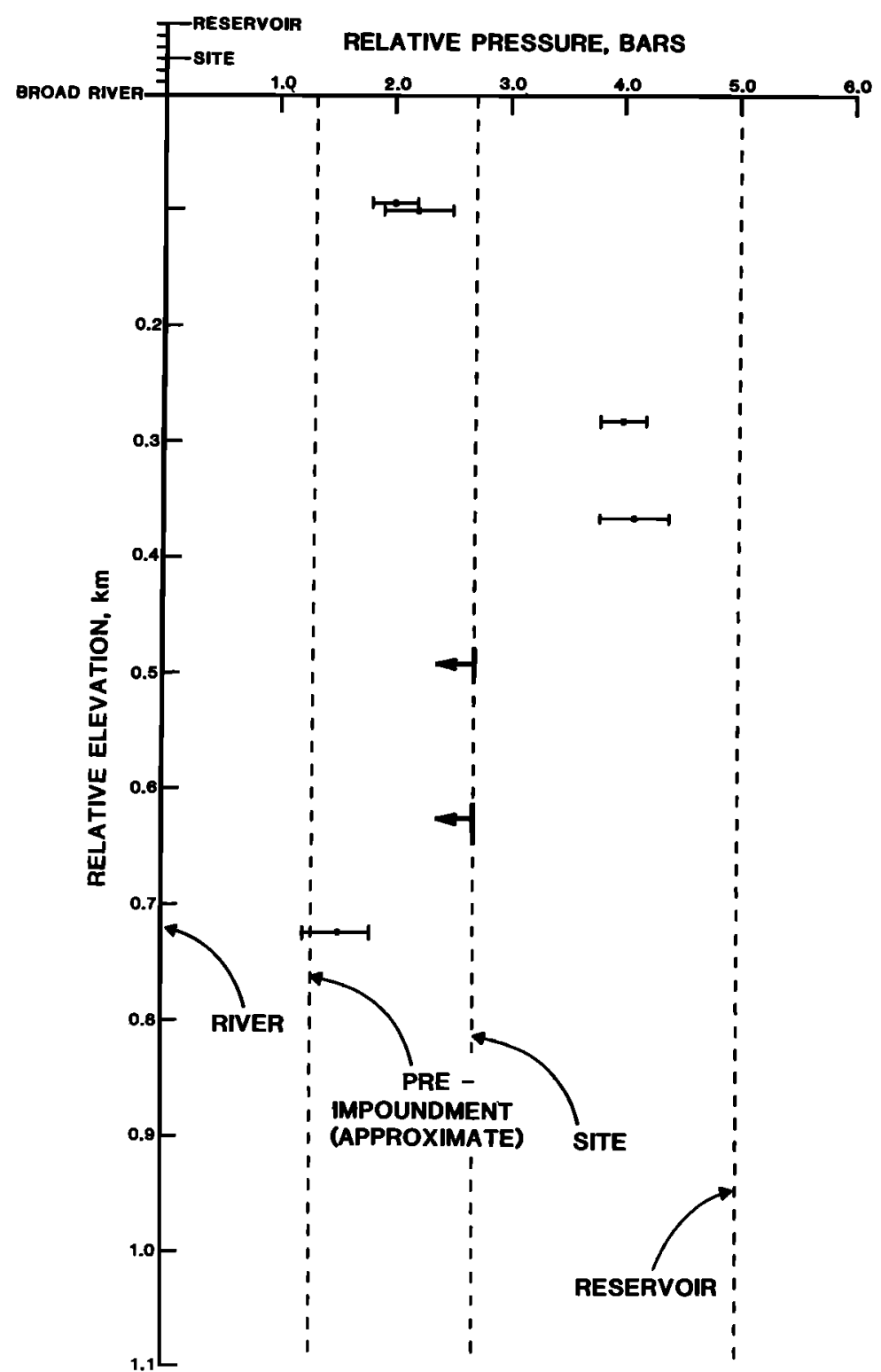

FRACTURES / 2 METERS
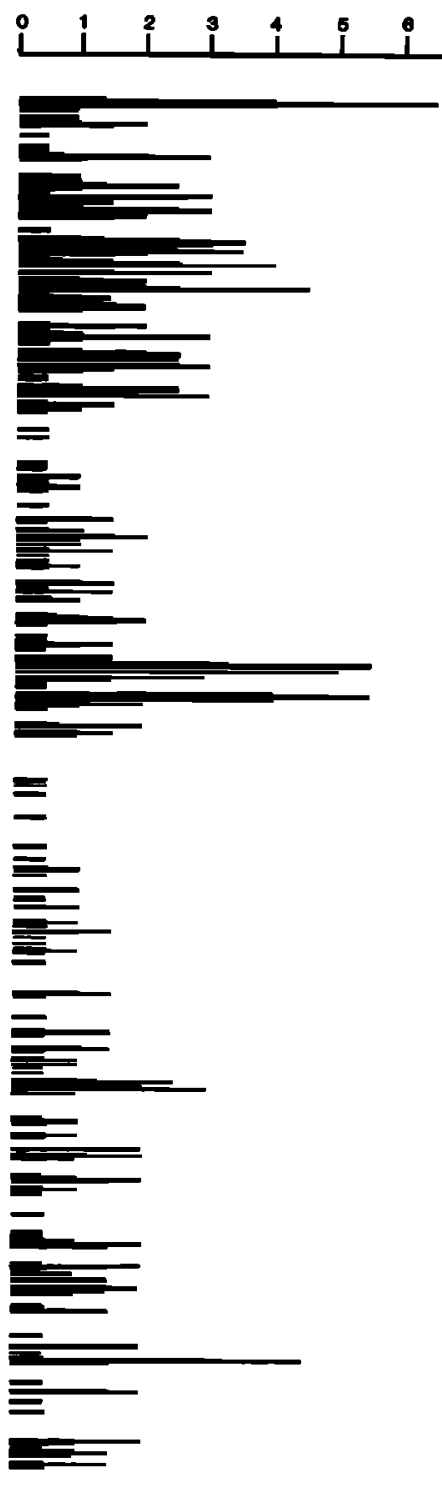

Fig. 10. Relative pore pressure in Mont 2 referenced to the elevation of the Broad River and the pore pressure appropriate to a water table at that depth. In the upper left-hand corner of the figure the relative elevation of the river, reservoir, and drill site are shown. Straight vertical lines in the figure represent pore pressure under water table conditions for the indicated elevation. At the right edge of the figure are the fracture densities observed in Figure $6 b$ appropriately shifted for depth.

in Mont 1 all yielded bulk permeability values of about 1 mdarcy $\left(10^{-11} \mathrm{~cm}^{2}\right)$. The value for the interval from 539 to $869 \mathrm{~m}$ in Mont 2 , however, was only about $10^{-2}$ mdarcy. This is apparently caused by the paucity of fractures in this part of the hole and the significant amount of alteration to zeolite and clay in the fracture zones (D. Prowell, personal communication, 1981).

\section{Discussion}

A relatively simple way to view pore fluid diffusion is to consider one-dimensional flow resulting from a nearly instantaneous change in pressure. In this case the characteristic time period for pore pressure equilibration $t^{*}$ at a given distance $l$ from the source of pressure is simply given by

$$
t^{*} \simeq l^{2} / C
$$

where $C$ is the hydraulic diffusivity [after Carslaw and Jaeger, 1959]. A plot of the logarithm of distance as a function of the logarithm of time yields straight lines for a given diffusivity. Figure 12 presents such a plot in which we have converted from permeability to diffusivity using

$$
C=k / \phi \eta \beta
$$

where $\phi$ is the average porosity of the rock and $\eta$ and $\beta$ are the viscosity and compressibility of water respectively. Using $\phi=0.1 \%, \eta=10^{-2} \mathrm{P}$, and $\beta=3.2 \times 10^{-5} \mathrm{bar}^{-1}$, a permeability of 1 mdarcy corresponds to a diffusivity of about $3 \times 10^{4} \mathrm{~cm}^{2} / \mathrm{s}$.

Also shown in Figure 12 is the approximate time history of Monticello seismicity. The observed time behavior of the seismicity appears to agree quite well with that expected for the diffusion model with a permeability of 1 mdarcy. We 


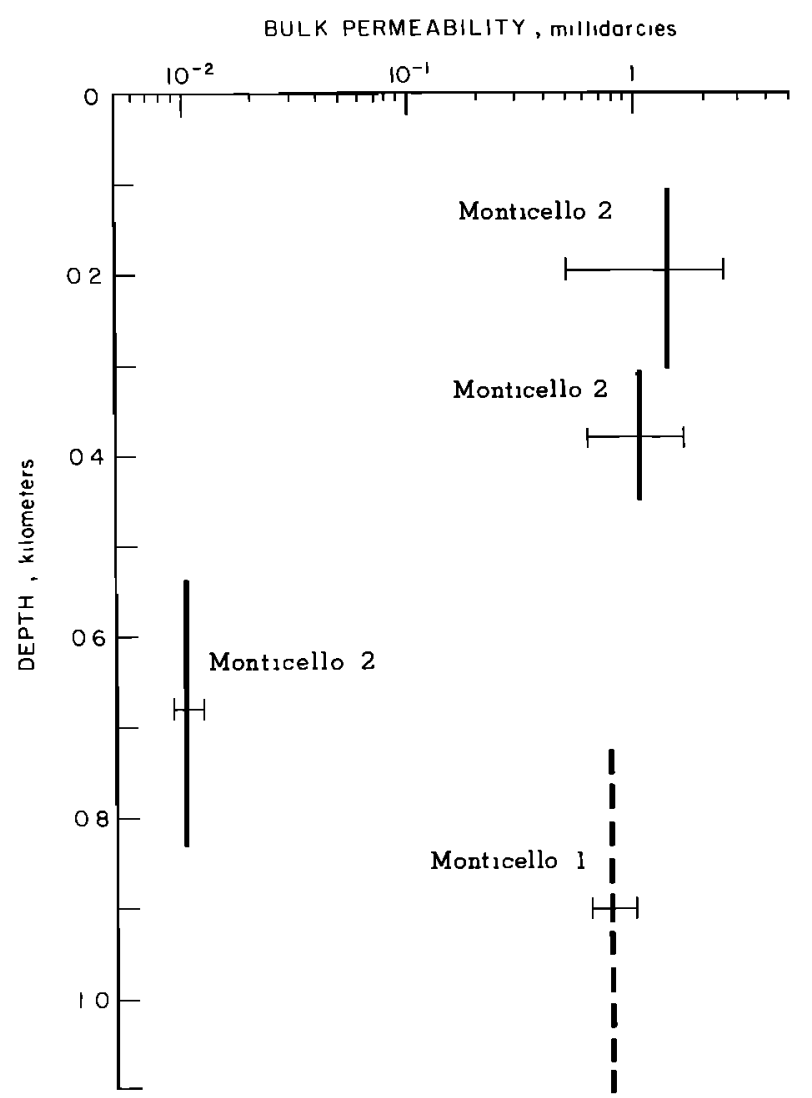

Fig. 11. Bulk permeability measurements in wells Mont 2 (solid lines) and Mont 1 (dashed line). The relatively large error bars are due to the accumulated error associated with differencing transmissivity tests (see text).

observe in Figure 12 that for a bulk permeability of 1 mdarcy, the expected onset of activity within about $1 \mathrm{~km}$ of the reservoir is about 1 week, and we see in Figure 2 that the major onset of earthquake activity started about 1 week after the major increase in lake level began on about December 13, 1977. The January and February 1978 burst of activity (with most earthquakes occurring within $3 \mathrm{~km}$ of the reservoir) occurred within 2 months after reservoir impoundment. For a permeability of 1 mdarcy, this is about what is expected. Even though we do not know the exact value of pore pressure required to trigger the events, Talwani [1981] demonstrates that the characteristic time for diffusion $t^{*}$ is within an order of magnitude of the time required for the pore pressure to change from about 3 to $90 \%$ of its final value. Thus $t^{*}$ is an approximate measure of the time in which the pore pressure changed from its preimpoundment to postimpoundment values.

In Figure 12 we interpret the seismicity to date as having occurred in two stages. In the first stage, from the time of reservoir impoundment to about 3 months after impoundment, seismicity was occurring in a diffusion-controlled mode: the size of the epicentral zone was growing as a function of time in a manner similar to what has been observed at a number of reservoirs (P. D. Talwani et al., manuscript in preparation, 1982). The second stage of seismic activity began in this interpretation about 3 months after impoundment. We label this stage as having restricted epicentral growth because the epicentral zone stopped grow- ing with time for possible reasons which are discussed below.

\section{Discussion}

The measurements described above seem to confirm the hypothesis that the induced earthquakes that have occurred at Monticello Reservoir are the result of reverse slip motion on preexisting fractures at very shallow depth and that the near-surface pore pressure change caused by reservoir impoundment was sufficient to trigger the earthquakes. In this section we discuss this hypothesis and examine its implications. Critical questions include Are the stress measurements reasonable? Where are future events likely to occur? Are the expectable earthquake magnitudes similar to those of the earthquakes which have already occurred?

\section{Near-Surface Stress Field}

The in situ stress measurements in the Monticello wells seem unusual in that relatively high horizontal stresses are evident only in the upper few hundred meters. As this observation has important implications for the maximum earthquake magnitude, we should consider the stress measurements in light of other data.

Stress measurements at shallow depths in crystalline rock typically show (1) that both horizontal principal stresses exceed the lithostat and (2) that the greatest principal stress typically is near a critical value for reverse faulting to a few hundred meters depth. This latter point is illustrated in Figure 13 [after Brace and Kohlstedt, 1980; McGarr and Gay, 1978]. Data primarily from mines in the Great Lakes area of Canada (Figure 13a) indicate conditions of incipient reverse faulting to depths of $\sim 700 \mathrm{~m}$, and stress measurements from South African mines (Figure 13b) indicate a condition nearly the same as that at Monticello Reservoir;

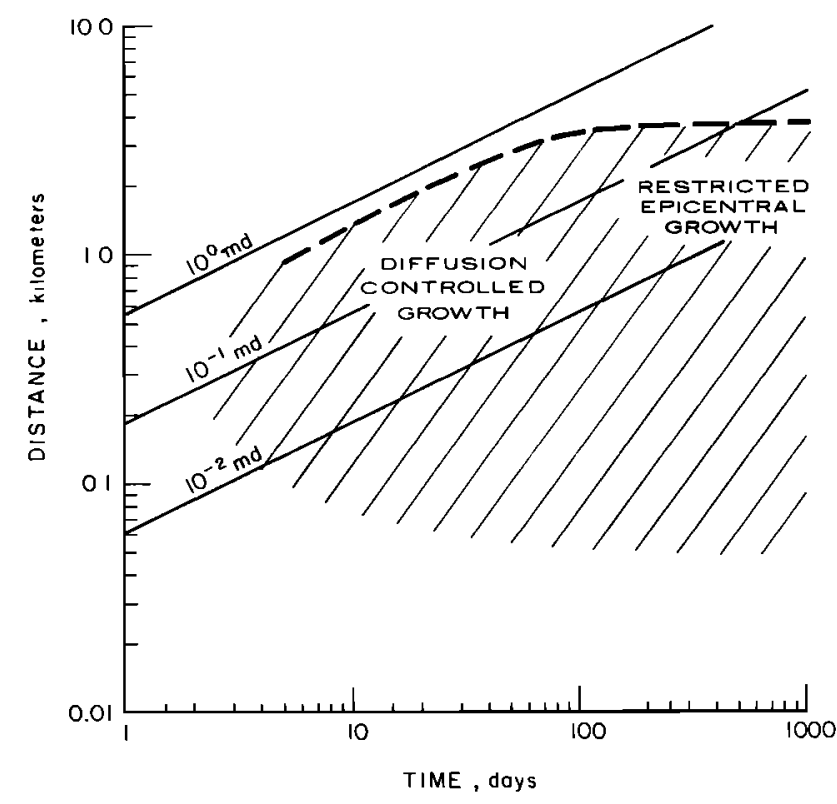

Fig. 12. Relationship between characteristic diffusion time $t^{*}$ and distance for different permeabilities and the approximate time and distance over which seismicity has occurred (shaded areas). The region labeled diffusion controlled growth refers to the initial period after impoundment when the epicentral zone increased with time due to fluid diffusion. The shaded area labeled restricted epicentral growth indicates that the seismicity after the maximum size of the epicentral zone had already been established. 


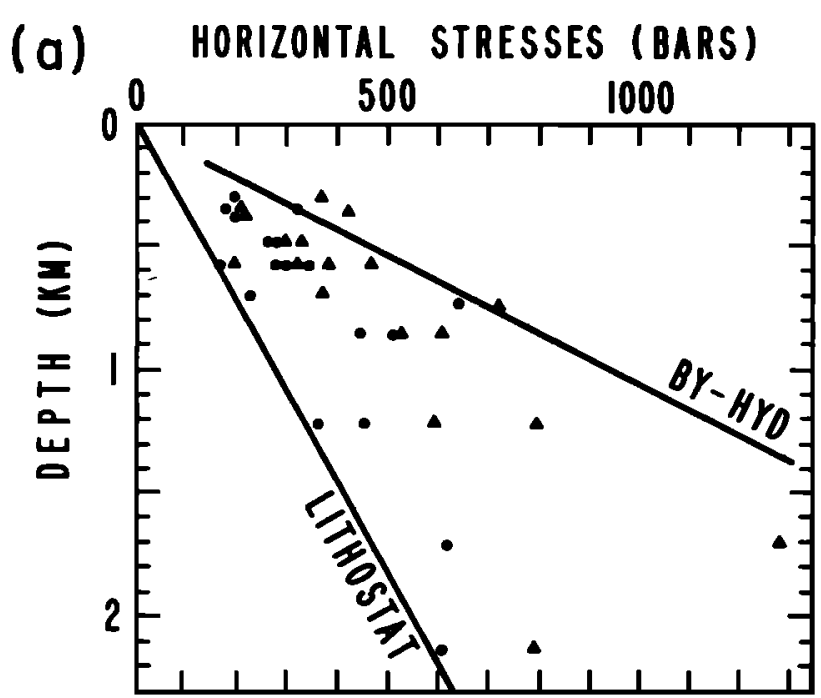

(b)

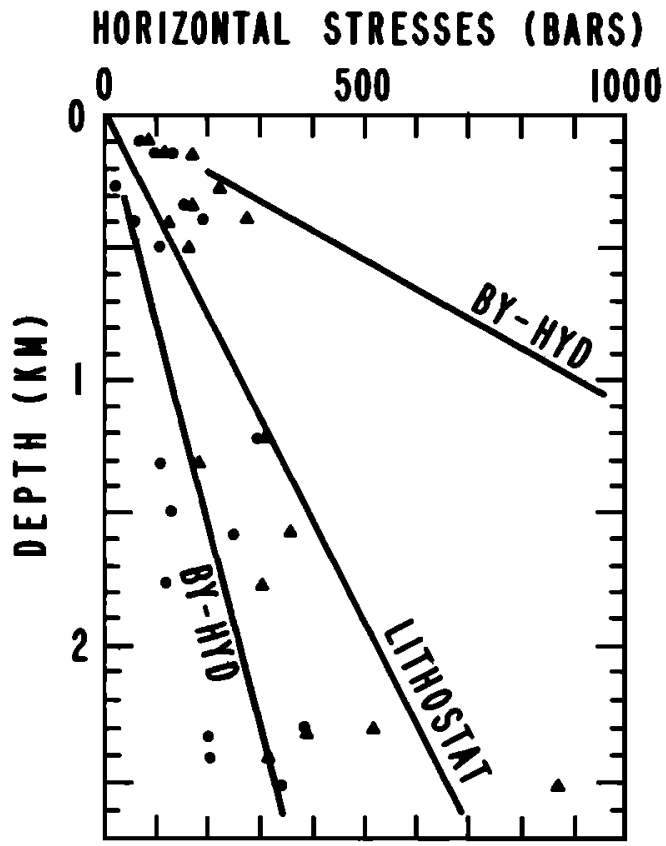

Fig. 13. Compilation of stress measurements from Canada (Figure 13a) and South Africa (Figure 13b) compared to the critical stress for frictional sliding on well-oriented faults [after Brace and Kohlstedt, 1980; McGarr and Gay, 1978]. BY-HYD refers to a friction law from Byerlee [1968], assuming hydrostatic pore pressure similar to the $S_{H}$ critical area shown in Figures 4 and 5.

incipient thrust faulting is apparently active in only the upper 200-300 $\mathrm{m}$ of the crust. These data, then, suggest that measurements of high horizontal compressive stresses at very shallow depths are quite common in areas which, like the Monticello Reservoir area, have little tectonic activity.

\section{Future Activity}

In considering where future earthquake activity is likely to take place, two important questions require discussion. What physical process has limited the growth of the epicentral zone? Why do infrequent minor bursts of activity continue to occur within the epicentral area that was defined within the first few months after impoundment? In considering the second question, the best explanation seems to be that diffusion of pore pressure is occurring into isolated less permeable zones. Considering Figure 12, it takes about 1 year for the pore fluid to diffuse $1 \mathrm{~km}$ in a medium with a permeability of 0.01 mdarcy, the lowest measured value. Thus it is expected that activity will continue as diffusion into isolated low permeability zones occurs, and it appears that some of the seismicity gaps observed in Figure 3 may subsequently be filled. In situ stress and permeability measurements in these gaps would help determine if they have not yet been active because the stresses are high but the permeability is low (in which case there could be future activity) or if they will never be active because the stresses are not near critical.

According to Figure 12, within about 100 days after impoundment the zone of elevated pore pressure had extended 4-5 km from the reservoir if the measured permeability of 1 mdarcy is indeed representative. A 4-km distance includes all the seismicity that has occurred since reservoir filling (Figure 3), and the entire zone in which seismicity has occurred was essentially defined in the first 2 months of activity [Talwani, 1979]. But what physical mechanism has restricted the epicentral zone to the area immediately adjacent to the reservoir? Three possible mechanisms come to mind: (1) the state of stress may not be critical outside of the zone already defined by seismicity, (2) the distribution of fractures and joints may be so different outside the zone of seismicity that either no well-oriented potential fault planes exist or that there are so few fractures and joints that the permeability is extremely low, or (3) that due to the hydrology of the area, the impoundment of the reservoir has had no appreciable effect on the preimpoundment subsurface pore pressure outside of this zone. Only the last explanation seems reasonable. Although we do not have data from the surrounding region, there is no reason to suspect a priori that either the state of stress or the fracture systems are markedly different. However, the fact that the seismicity has been limited to the close proximity of the reservoir strongly suggests that the impoundment has had no affect on subsurface pore pressure at distances more than about $4 \mathrm{~km}$ from the reservoir. Considering 1 mdarcy as a reasonable nearsurface permeability, sufficient time has already elapsed for diffusion to reach $>10 \mathrm{~km}$ if it was likely to occur. We suspect that the natural hydrologic conditions around the reservoir have prevented fluid diffusion from affecting the subsurface pore pressure beyond the hills and ridges adjacent to the reservoir and have thus limited the growth of the epicentral zone.

\section{Maximum Magnitude}

On the basis of the relative paucity of induced earthquakes with magnitudes greater than 2.0 relative to expectations based on the number at smaller magnitude (i.e., the $b$ slope), P. D. Talwani et al. (manuscript in preparation, 1982) conclude that the maximum magnitude for an induced earthquake at Monticello Reservoir is about 3.0. From other lines of evidence, they suggest that the maximum magnitude may be as large as 4.0. Let us briefly consider this question from the perspective of the measurements described above in terms of whether the proposed mechanism approximately predicts the maximum magnitude of the past activity (a magnitude 2.8 event) and whether this can be used as an estimate for the magnitude of future induced seismicity.

The in situ stress measurements strongly suggest that 
unless the stress field has been markedly affected by earthquakes with stress drops approaching 50 bars, the maximum depth at which stress is close to failure is only $200-300 \mathrm{~m}$. It follows, then, that only a small fault area can be involved in any future earthquake. Various empirical relationships between fault length or fault area and magnitude have been established [see Mark, 1977; Bolt, 1978; Wyss, 1979], but these relationships exhibit considerable scatter and were obtained for significantly larger earthquakes than those occurring at Monticello Reservoir. The relationship between magnitude and fault area $A$ derived by Wyss [1979] for earthquakes of $M>5.6$ is

$$
M=\log A+4.15
$$

where $A$ is in $\mathrm{km}$. If this relationship can be extrapolated down to magnitude 3.0 , a fault area of $0.071 \mathrm{~km}^{2}$ is predicted. This corresponds to a square slip area $265 \mathrm{~m}$ in dimension. Although this appears to agree quite well with the maximum fault depth implied by the stress measurements, the validity of (9) for earthquakes in the magnitude range of interest is unclear. Furthermore, if a fault with a much greater length than depth was active, larger earthquakes could be expected, but the clusterlike distribution of earthquakes and the lack of such features in outcrops [Secor et al., this issue] suggest that this is not likely.

\section{Future Monitoring}

Because of the rapid decrease in permeability at depths greater than $0.5 \mathrm{~km}$ observed in Mont 2, it may take years for diffusion to occur to depths greater than $1 \mathrm{~km}$. It is therefore critical to maintain accurate seismic monitoring at Monticello Reservoir. Unless activity ultimately begins to migrate to greater depths the earthquakes that are expected to occur in the future should have a similar magnitude to those that have already occurred $\left(M_{L} \leq 3.0\right)$. The stress field at depths greater than $\sim 1 \mathrm{~km}$ was not sampled directly, and it is difficult to predict the stress magnitudes at greater depth due to the apparent heterogeneity of the stress field. It is conceivable, however, that earthquake depths might begin to increase. If so, it may mean that a mechanism other than that discussed above is responsible for the seismicity and that the implications of the mechanism proposed are no longer applicable.

\section{APPENDIX}

The pressure and flow records for the hydraulic fracturing measurements are presented in Figures A1 and A2. The data presented were recorded from pressure and flow transducers at the surface. The pressure data actually used for computation of the in situ stresses were primarily from a downhole pressure recorder, the records from which are not amenable to reproduction. During pumping the pressure records presented here are affected by a pressure gradient in the hose between the transducer and the well head. The magnitude of the pressure drop due to this gradient is 10-20 bars at the flow rates used. No appreciable pressure gradient due to flow occurs in the drill pipe. To obtain downhole pressure (uncorrected for this pressure drop) from the surface records, simply add the hydrostatic pressure indicated in Table 1. In Figures $A 1$ and $A 2$, negative flow refers to flow out of the well after a fluid injection cycle. Notable characteristics of the data are as follows.

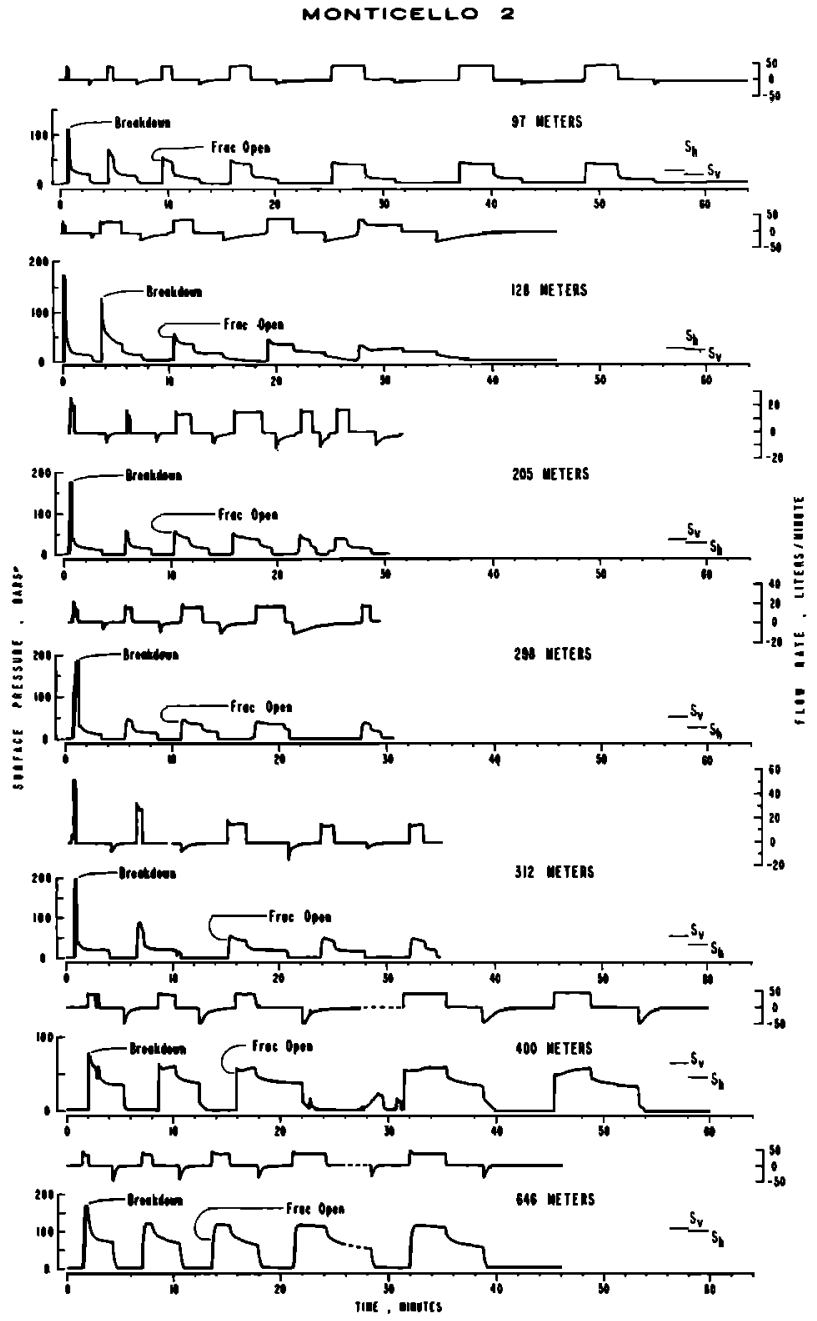

Fig. A1. Pressure and flow records from Mont 2. Positive flow corresponds to fluid injection and negative flow corresponds to flow-back out of the hydraulic fracture.

\section{Mont 2 (Figure Al)}

$97 \mathrm{~m}$. On the later cycles the instantaneous shut-in pressure is equal to the lithostatic stress. This indicates that the fracture turned into a horizontal plane after leaving the wellbore [see Zoback et al., 1977]. Downhole pumping pressure was therefore used for the interpretation of $S_{h}$.

$128 \mathrm{~m}$. Large pressure peak at beginning of cycle 2 indicates incomplete breakdown in cycle 1. Pump clogged during cycle 5 .

$400 \mathrm{~m}$. This record is a good test (stable shut-in and pumping pressure) in which several unusual things happened. On cycle 1 the pump was briefly shut off. The pressure buildup after cycle 3 is due to choking the flowback value. Pump problems caused the unusual pressurizations between cycles 3 and 4 . The tensile strength determined for this test was unusually low.

$646 \mathrm{~m}$. The dashed part of this record was caused by temporary computer failure.

\section{Mont 1 (Figure A2)}

$165 \mathrm{~m}$. Rapid decay of pressure during shut-in to a value near the lithostatic stress indicates a hydraulic fracture turning into a horizontal plane. 


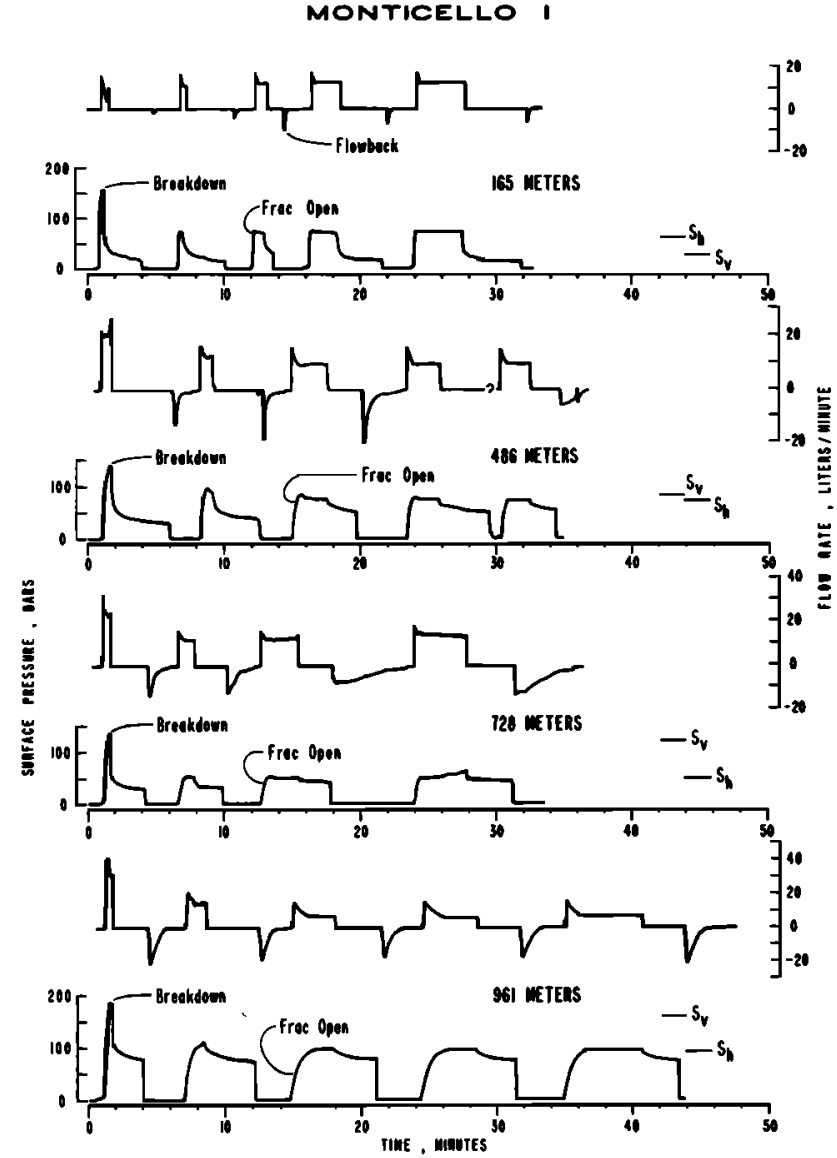

Fig. A2. Pressure and flow records from Mont 1. Positive flow corresponds to fluid injection and negative flow corresponds to flow-back out of the hydraulic fracture.

$961 \mathrm{~m}$. Due to the low and variable flow rate on cycles 35 the fracture opening pressure is difficult to determine accurately.

Acknowledgments. The assistance of Joseph Svitek, Rich Liechti, Don Seeburger, David Amick, and John Roller made this study possible. The comments of Art McGarr, Joe Fletcher, David Simpson, and Pradeep Talwani improved this manuscript. We thank Pradeep Talwani for allowing us to refer to his unpublished focal mechanism data.

\section{REFERENCES}

Anderson, T. O., and E. J. Stahl, A study of induced fracturing using an instrumental approach, J. Petrol. Technol., 261-267, 1967.

Barenblatt, G. I., I. P. Zheltov, and I. N. Kochina, Basic concepts in the theory of seepage of homogeneous liquids in fisured rocks, J. Appl. Math. Mech., 24, 852-864, 1960.

Bell, M. L., and A. Nur, Strength changes due to reservoir-induced pore pressure and stresses and application to Lake Oroville, $J$. Geophys. Res., 83, 4469-4483, 1978.

Biot, M. A., General theory of three-dimensional consolidation, $J$. Appl. Phys., 12, 155-164, 1941.

Bolt, B. A., Incomplete formulations of the regression of earthquake magnitude with surface fault rupture length, Geology, 6, 233-235, 1978.

Brace, W. F., and D. L. Kohlstedt, Limits on lithospheric stress imposed by laboratory experiments, J. Geophys Res., 85, 6248$6252,1980$.

Bredehoeft, J. D., and S. S. Papadopoulus, A method for determining the hydraulic properties of tight formations, Water Resour. Res., 16, 233-238, 1980.

Bredehoeft, J. D., R. G. Wolff, W. S. Keys, and E. Shuter,
Hydraulic fracturing to determine the regional in-situ stress field Piceance Basin, Colorado, Geol. Soc. Am. Bull., 87, 250-258, 1976.

Byerlee, J. D., Brittle-ductile transition in rocks, J. Geophys. Res., 73, 4741-4750, 1968.

Byerlee, J. D., Friction of rocks, Pure Appl. Geophys., 116, 615626, 1978.

Carder, D. S., Seismic investigations in the Boulder Dam area, 1940-1944, and the influence of reservoir loading on earthquake activity, Bull. Seismol. Soc. Am., 35, 175-192, 1945.

Carslaw, H. S., and J. C. Jaeger, Conduction of Heat in Solids, 2nd ed., 510 pp., Oxford University Press, New York, 1959.

Cooper, H. H., Jr., J. D. Bredehoeft, and I. S. Papadopoulus, Response of a finite diameter well to an instantaneous charge of water, Water Resour. Res., 3, 263-269, 1967.

Dames and Moore, Supplemental geologic investigation Virgil C. Summer Nuclear Station-unit one Fairfield County, South Carolina for South Carolina Electric and Gas Company, 61 pp., Bethesda, Md., 1974.

Enever, J. R., and B. A. Wooltorton, Experience with hydraulic fracturing as a means of estimating in situ stress in Australian coal basin sediments, in Proceedings of the Workshop on Hydraulic Fracturing Stress Mechanics, U.S. National Committee on Rock Mechanics, Washington, D. C., in press, 1982

Fletcher, J. B., A comparison between the tectonic stress measured in situ and stress parameters from seismic waves at Monticello, South Carolina; J. Geophys. Res., this issue.

Gough, D. I., and W. I. Gough, Time dependence and trigger mechanisms for the Kariba (Rhodesia) earthquakes, Eng. Geol., 10(2-4), 211-218, 1976.

Haimson, B. C., Near-surface and deep hydrofracturing stress measurements in the Waterloo quartzite, paper presented at the 19th U.S. Symposium on Rock Mechanics, Univ. of Nev., Reno, 1978.

Haimson, B. C., and C. Fairhurst, In-situ stress determination at great depth by means of hydraulic fracturing, in Rock Mechanics-Theory and Practice, Proceedings, 11th Symposium on Rock Mechanics, Berkeley, 1969, chap. 28, edited by W. H. Somerton, pp. 559-584, Society of Mining Engineers of AIME, New York, 1970.

Hanks, T. C., Earthquake stress drops, ambient tectonic stresses, and stresses that drive plate motions, Pure Appl. Geophys., 115 , 441-458, 1977.

Healy, J. H., W. W. Rubey, D. T. Griggs, and C. B. Raleigh, The Denver earthquakes, Science, 161, 1301-1310, 1968.

Hickman, S., and M. D. Zoback, The interpretation of hydraulic fracturing pressure-time data for in situ stress determination, in Proceedings of the Workshop on Hydraulic Fracturing Stress Mechanics, U.S. National Committee on Rock Mechanics, Washington, D. C., in press, 1982.

Hubbert, M. K., and W. W. Rubey, Mechanics of fluid-filled porous solids and its applications to overthrust faulting, Geol. Soc. Amr. Bull., 70, 115-166, 1959.

Hubbert, M. K., and D. G. Willis, Mechanics of hydraulic fracturing, J. Petrol. Technol., 9, 153-168, 1957.

Jaeger, J. C., and N. G. W. Cook, Fundamentals of Rock Mechanics, 513 pp., Metheun, London, 1969.

Lee, W. H. K., and J. C. Lahr, A computer program for determining hypocenter, magnitude, and first motion pattern of local earthquakes: Revision of HYPO71, U.S. Geol. Surv. Open File Rep., 100 pp., 1972.

Mark, R. K., Application of linear statistical models of earthquake magnitude versus fault length in estimating maximum expectable earthquakes, Geology, 5, 464-466, 1977.

Mathews, C. S., and D. G. Russel, Pressure Build-up and Flow Tests in Wells, Monogr., no. 1, 167 pp., Society of Petroleum Engineers, Dallas, Tex., 1967.

McGarr, A., and N. C. Gay, State of stress in the earth's crust, Annu. Rev. Earth Planet. Sci., 6, 405-436, 1978.

Overstreet, W. C., and H. Bell III, The crystalline rocks of South Carolina, U.S. Geol. Surv. Bull., I183, 126 pp., 1965.

Parsons, R. W. Permeability of idealized fractured rock, Soc. Petl. Eng. J., 6, 126-136, 1966.

Raleigh, C. B., J. H. Healy, and J. D. Bredehoeft, Faulting and crustal stress at Rangley, Colorado, in Flow and Fracture of Rocks, Geophys. Monogr. Ser., vol. 16, edited by H. C. Heard, pp. 275-284, AGU, Washington, D. C., 1972. 
Raleigh, C. B., A. McGarr, and M. D. Zoback, Hydraulic fracture gradients, normal faulting, and $\mu$, Eos Trans. AGU, 53, 1227, 1977.

Secor, D. T., Jr., Geological studies in an area of induced seismicity at Monticello Reservoir, South Carolina, first technical report contract 14-08-0001-19124, 34 pp., U.S. Geol. Surv., Reston, Va., 1980.

Secor, D. T., Jr., L. S. Peck, D. M. Pitcher, D. C. Prowell, D. H. Simpson, W. A. Smith, and A. W. Snoke, Geology of the area of induced seismic activity at Monticello Reservoir, South Carolina, J. Geophys. Res., this issue.

Seeburger, D. A., and M. D. Zoback, The distribution of natural fractures and joints at depth in crystalline rock, J. Geophys. Res., $87,5517-5534,1982$.

Simpson, D. W., Seismicity changes associated with reservoir loading, Eng. Geol., 10, 123-150, 1976.

Snow, D. T., Geodynamics of seismic reservoirs, in Proceedings of the Symposium on Percolation Through Fissured Rocks, Deutsche Gesellschaft für Erd- und Grundbau, Stuttgart, 1972.

South Carolina Electric and Gas Company, Virgil C. Summer nuclear station, Final safety and analysis report to U.S. Nuclear Regulatory Commission, vol. II, amendment 2, section 2.4.13, Columbia, June 1977.

South Carolina Electric and Gas Company, Virgil C. Summer nuclear station unit 1 , Supplemental seismological investigation, submitted to U.S. Nuclear Regulatory Commission, Columbia, Dec. 1980.

Talwani, P. D., Induced seismicity and earthquake prediction studies in South Carolina, eighth technical report, contract 14-080001-14553, U.S. Geol. Surv., Reston, Va., 1979.

Talwani, P. D., Hydraulic diffusivity and reservoir induced seismicity, final technical report, 48 pp., U.S. Geol. Surv., Reston, Va., 1981.
Talwani, P. D., and B. K. Rastogi, Mechanism for reservoir induced seismicity, Earthquake Notes, 49, 59, 1979.

Talwani, P. D., B. K. Rastogi, and D. Stevenson, Induced seismicity and earthquake prediction studies in South Carolina, tenth technical report, contract 14-08-0001-17670, U.S. Geol. Surv., Reston, Va., 1980.

Withers, R. J., and E. Nyland, Time evolution of stress under an artificial lake and its implication for induced seismicity, Can.J. Earth Sci., 15, 1526-1534, 1978.

Woodward-Clyde Consultants, Study of reservoir induced seismicity, technical report, contract 14-08-0001-16809, U.S. Geol. Surv., Reston, Va., 1979.

Wyss, M., Estimating maximum expectable magnitude of earthquakes from fault dimensions, Geology, 7, 336-340, 1979.

Zemanek, J., E. Glenn, C. J. Norton, and R. L. Cardwell, Formation evaluation by inspection with the borehole televiewer, Geophysics, 35, 254-269, 1970.

Zoback, M. D., J. Healy, and J. Roller, Preliminary stress measurements in central California using the hydraulic fracturing technique, Pure Appl. Geophys., I15, 135-152, 1977.

Zoback, M. D., H. Tsukahara, and S. Hickman, Stress measurements at depth in the vicinity of the San Andreas fault: Implications for the magnitude of shear stress at depth, J. Geophys. Res., $85,6157-6173,1980$.

Zoback, M. L., and M. D. Zoback, State of stress in the conterminous United States, J. Geophys. Res., 85, 6113-6156, 1980.
(Received October 1, 1981;

revised April 15, 1982;

accepted April 23, 1982.) 